ODA ARCHIVE - T1305ICI

$1995 \%$

\title{
Hydrological Information Transfer Using HOMS
}

\section{ABSTRACT}

The Hydrological Operational Multipurpose Subprogramme (HOMS) scheme of the World Meteorological Organization (WMO) consists of an international network for the transfer of packages of proven hydrological know-how, with particular emphasis on helping developing countries. More than one hundred HOMS centres worldwide produce and supply information components and handle requests for components for use in their own countries. Details are presented of the organization and operation of HOMS.

UK HOMS REPRESENTATIVE:

Dr Howard R Oliver

Institute of Hydrology

Wallingford

Oxford Ox10 8BB

Office Tel 01491692393

Operator 01491838800

Fax 01491692424

Telex 849365 HYDROL G

Email h.oliver@ioh.ac.uk 


\section{INTRODUCTION}

Th1s report contalns a general description of the HOMS scheme together with a full listing of all avallable HOMS components and the hOMS National Reference Centres. It has been extracted from the HOMS manual, full coples of which are held at all hOMS offices.

Further details of specific components, sequences etc referred to in these eztracts can be provided on request.

The HOMS scheme is always very pleased to recelve suggestions for possible new components and offers should please be made direct to the main UK HOMS National Reference Centre in Wallingford.

The operation of the UK National Reference Centre is funded by the Overseas Development Administration. 



\section{II.1 TECHNICAL STRUCTURE OF HOMS}

\section{II.1.1 Terminology and definitions}

To enable a wide variety of hydrological technology to be made available for use in differing circumstances, HOMS has adopted a modular structure. The basic modules of this structure, HOMS components are the items of hydrological technology provided to HOMS by Members of wo for transfer to other interested Members. Each component is a self-contained entity, which cannot be further subdivided without destroying its functions or usefulness. and should in general be able to work on its ow to perform some specific hydrological task. Components are classified into sections dealing with the basic activities carried out by a hydrological service, viz: network design, instrumentation, data collection and transmission, data processing and storage, hydrological modelling, etc. Sections are further divided into subsections to provide a more detailed division of the subject matter of HOMS. See Part III below for a fuller description of the types of components available and of the classification system.

HOWS components are also available at different levels of complexity. ranging from simple manual techniques to those involving sophisticated computer software. In many instances, two or more alternative components are available to meet a particular need. These may be at different levels of complexity, or simply reflect different approaches to the same basic problem.

Components may be grouped into HOMS sequences: logical aggregations of HOMS components, which may be applied to meet some requirement for hydrological information. The concept of sequences is described more fully in Part IV below.

Finally, HOMS user requirements give advice to users of HOMS as to how they might fulfil their requirements for hydrological information. These include information on the components and sequences which might be applied for some major hydrological problem such as design of a reservoir spillway, or flood plain zoning, and comparative analyses of the intended fields of application of different components with similar purposes. See Part IV for a fuller description.

\section{II.1.2 Standards and criteria}

HOMS components are required to meet the standards and recomendations laid down in such wMO regulatory and guidance material as the WMO Technical Regulations, Vol. III - Hydrology, and the Guide to Hydrological Practices. In addition it is recommended that components meet other relevant standards of such bodies as the International Organization for Standardization (ISO) . 


\section{II.2. ADMINISTRATION}

\section{II.2.1 General}

HOMS provides an international framework for the co-ordination and promotion of technology transfer in operational hydrology between the Members of whso. It was established as a subprogramme of the pre-existing operational Operational Hydrology Programe (OHP) of wMO by the WMO Eight Congress (1979) by its Resolution 30 (Cg-VIII). Resolution 25 ( $\mathrm{Cg}-\mathrm{IX})$ lays down a plan for the second phase of HOMS (1984 to 1991). Resolution 30 (Cg-VIII) established HOMS as a co-operative effort of Members, with co-ordination of national activities through the wMo Commission for Hydrology ( $\mathrm{CH} y)$.

\section{II.2.2 HOMS National Reference Centres}

Members of WMO which wish to participate in HOMS do so by designating a HOMS National Reference Centre. This centre, which is usually established in the national Hydrological Service, has responsibility for co-ordination of HOMS activities within the country and liaison with centres in other countries. The activities that need to be undertaken at the national level by HOWS National Reference Centres include:

- Establishment of an inventory of components which are currently available and operationally used in the country and which are considered appropriate to be proposed for inclusion in the HOMS project.

- Collection of these components, their adaptation as necessary. and transmission of their description to wmo for inclusion in the HOMS Reference Manual.

- At the request of other countries or of wo, transmission of these components, either bilaterally or through WMO, for use and application in other countries.

- Receipt and storage of components requested and received from other countries, either directly or through WMO.

- Calling the attention of potential users in the country to the availability of hoMS components.

- Assistance in the use and application of the HOMS components, as appropriate.

The details of the organization of the National Reference Centre are of course entirely a matter for national decision, taking into account existing national practices and structures. Formaliy, the centre is designated by the Permanent Representative of the country with wiMO who should communicate to the Secretary-General the name of the institution or service where the centre is established and the officer responsible for the centre. Annex $A$ of this Reference Manual lists existing HNRCs.

A number of international water resources bodies have established arrangements for assisting their member countries in HOMS activities. These regional focal points are also listed in Annex $A$. 


\section{II.2.3 International co-ordination}

As a project within the Operational Hydrology Programme, technical guidance and review of HOMS is the responsibility of the commission for Hydrology. The Advisory Working Group of the Commission acts as Steering Comittee for haks and rapporteurs and working groups of the Commission advise on the technical development of hass in the areas related to their terms of reference.

The following co-ordinating functions need to be carried out at the international level, by the Steering comittee:

- Ascertaining the needs of Members in the overall orientation of the project.

- Elaborating and distributing to Members general and specific guidance on the substance and form of HOMS components to be prepared at the national level.

- Preparing, maintaining and updating the HOWS Reference Manual and periodically distributing it to Members.

- Assisting in the technology transfer among Members, within the framework of the project.

Secretariat support is provided by the HOMS Office in the Hydrology and Water Resources Department of the wMO Secretariat. This office is responsible for:

- Keeping the HOMS Reference Manual up to date by the timely issue of supplements:

- Assisting with administrative formalities in the transfer of components, if necessary and requested:

- Arranging for assistance in the adaptation of components for use in developing countries;

- Advising on the availability of support from UNDP and VCP projects and, where appropriate, arranging for this support;

- Monitoring the operation of HOMS, including collection of statistics on transfers, assisting transfers, keeping track of unfulfilled requests, and identifying gaps in the components and sequences available:

- Requesting new components and sequences Eron appropriate HNRCs to cover gaps identified by the monitoring exercise, or by $\mathrm{CH}_{y}$ working groups and rapporteurs:

- Publishing the HOMS Nersletter.

The Secretary-General, in co-operation with the president of City submits reports to the WMO Executive Council, the Commission for Hydrology and the wimo Congress on the status of HOSS together with proposals for its further development. 


\title{
I I. 3 HOMS OPERATIONS
}

\section{II.3.1 Availability and use of HOMS components}

HOMS components are available to all Members of WMO, to their national services and agencies and to all international agencies for use in water resources projects requiring operational hydrology. Persons wighing to make use of the technology available through Hass should first consult the HOMS National Reference Centre (HNRC) for their country (see Annex A). International agencies and potential users in countries without a rnRC should contact the HOMS office in the who Secretariat by writing to:

\author{
The Secretary-General \\ World Meteorological Organization \\ Case,postale No. 5 \\ CH-1211 GENEVA 20 \\ Switzerland.
}

The HRRCs all hold a copy of the HOMS Reference Manual and are able to advise users on the selection of components appropriate to their needs. Once a selection has been made the HNRC can obtain the required components. In the case of a commercial user, such as a firm of consulting engineers, the user may be requested to sign a simple declaration that he will not charge his clients for the component apart, of course, from such costs as salaries. materials, etc. that he incurs in obtaining and using the component on the client's behalf.

Components are normally to be obtained from the HNRC where they originated, but there are exceptions to this rule and certain components can be obtained from the HOMS Office in the wMO Secretariat (typically those developed by WMO field projects) or from some other source. Paragraph 9. Availability. of the summary description of the component, indicates where the component can be obtained. In any case, to assist monitoring of HOMS. HNRCs are asked to keep the HOMS Office informed of the components they request and. in turn. of the requests they receive.

\section{II.3.2 Technical co-operation and training}

The existence of HOMS, and the consequent availability of HOMS components, does not eliminate the need for assistance to developing countries through technical co-operation. Indeed, the need often arises for assistance or training in the use of specific HOMS components. A number of avenues exist for the provision of this assistance: UNDP has established a number of regional projects in support of HOMS: UNDP national projects in water resources can often fund assistance; as can the wMo voluntary Co-operation Programe (VCP). In addition, a number of countries offering components are able to arrange training through bilateral aid agencies. As the situation necessarily changes from time to time, the HOWS office in the wMO Secretariat and/or the supplier of the component should be consulted as to the availability of assistance. 
It may also be noted that components can themselves be used in the training of hydrological staff. This applies not only to section $Y$. Training aids in operational hydrology, but to a wide range of other components as well. To asgist in the use of HOMS as a source of training material the chy rapporteur on training has developed a cross-reference between the topics in the WMO curricula for the training of personnel in operational hydrology and the subsections of HOMS. This is reproduced in Annex $G$ to this manual.

\section{II.3.3 Monitoring the operation of HOMS}

One of the duties of the HOMS Office in the wMO Secretariat is to monitor the operation of the subprograme. and to report on the development of Hais to relevant wo bodies including Congress, the Executive Council. and the Comission for Hydrology. This monitoring has two aspects: the collection of statistics on the transfer of components, and reports on the experience of using components.

For the collection of statistics. HNRCs are asked to inform the HOMS Office of the components that they request from other HNRCs. and of the components that they transfer. Perhaps the simplest method of doing this is for each HINRC to copy any correspondence with other HNRCs, concerning the transfer of HOMS components to the HOMS Office in the wMO Secretariat. Alternatively a separate report could be made. The basic information required is the number of the component, the date it was requested, and date of transfer. The HOMS Office maintains a computerized data base of transfers which can be consulted by HRRCs. Each HNRC is sent annually a copy of the information held about its transfers to ensure the accuracy and completeness of this data base.

Users of components are asked to report to the supplier on the use they make of a component and on their general experience with the component. These reports provide valuable feedback on components leading to their improvement. The INRC supplying a component should include a report form with the component when it is transferred. The HOMS Office in the who Secretariat can provide a sample pro forma for these reports, but HNRCs can develop their own, if they so wish.

\section{II.3.4 New components, sequences and user requirements}

As HOMS is intended to be dymamic and evolving to meet the needs of users new components and sequences are continually required to fill gaps in the existing coverage of the field of operational hydrology. and to meet the needs of new developments. The various working groups and rapporteurs of the WMO Commission for Hydrology have as part of their terms of reference responsibility for advising on the technical content of HOMS and. in particular recommending where new components are needed. Potential users of HOMS are particularly requested to report when their needs are not adequately met by existing components.

Before inclusion in HOMS, new components are approved by the Steering Committee for HOMS, on the advice where appropriate of a relevant Chy rapporteur. This approval ensures that the technology contained in the component is within the field of interest of Hass and that it is in accordance with wMO Technical Regulations and recommendations. The approval also ensures that the summary description. to be included in the Hows Reference Manual. accurately describes the component. 
An HNRC wishing to submit a new component should prepare a summary description and submit it to the HOMS Office. Guidelines on preparing a summary description are issued to all HNRCs and detail the information and format required. The HNRC submitting a component should advise on its classification (subsection) and level of complexity. Once the component has been approved, the summary description will be edited and published in a supplement to the HRM. It should be noted that components are to be submitted through National Reference Centres, and individuals who wish to submit components should contact their country's HRRC.

A similar procedure is followed in the approval of hass sequences and HOMS user requirements. HNRCs are urged when submitting a group of related components, to group them formally as a sequence and to submit the sequence together with the components. In addition, sequences and user requirements grouping existing components may also be submitted. 


\section{Part III HOKS components}

\section{III.l TYPES OF HOMS COMPONENTS}

HOMS components usually take one of the three following forms:

Instruments and equipment

HOMS components relating to instruments and equipment offer specifications or descriptions of an instrument, or instructions, including working drawings, for making an instrument, rather than the instrument itself. When a number of components relating to the same basic instrument (for example water level recorders, or current meters) are available, the components are combined into a comparative catalogue of the type of instrument concerned. These catalogues are produced with the assistance and advice of the Hydrological Services of the Members of WMO to include the makes of instrument that they themselves use in their normal operations. Each catalogue contains a description of the various instruments concerned written to a standard format, and where available, manufacturer's brochures. Once written, these catalogues replace the individual components dealing with the instruments of the given type in the HOMS Reference Manual.

\section{Computer software}

Many components consist of computer programs developed to carry out comon hydrological computations. The material transferred will normally be the program itself in machine readable form, that is on cards, diskette, or magnetic tape, together with user manuals describing how to use the program. Paragraph 6. Form of presentation of the summary description will specify such details as the media (tape, diskette, etc.) on which the program can be obtained, and the computer language in which it is written. Emphasis is laid on using standard forms of such common languages as FORTRAN or BASIC in preparing components.

\section{Technical and general guidance manuals}

These describe the steps to be carried out in performing some hydrological task. or give general guidance on hydrology or water resources assessment. Examples include a manual describing how to measure the discharge of a stream using a current meter or advice on the design of networks for measuring particular hydrological elements. Some manuals describe how to perform simple hand calculations of, say. storm runoff, which at a higher level of complexity would be done by a computer program.

\section{III.2 BASIS FOR CLASSIFICATION}

Each HOMS component is given a unique component number by which it may be referenced. So that these numbers may be of help to users in locating the components they require. part of the component number is a subject classification code for the components. For the purpose of this classification the subject matter of HOMS is divided into 13 sections each designated by a letter. These secticns largely follow the major sequence of activities of an operational hydrological service viz: 


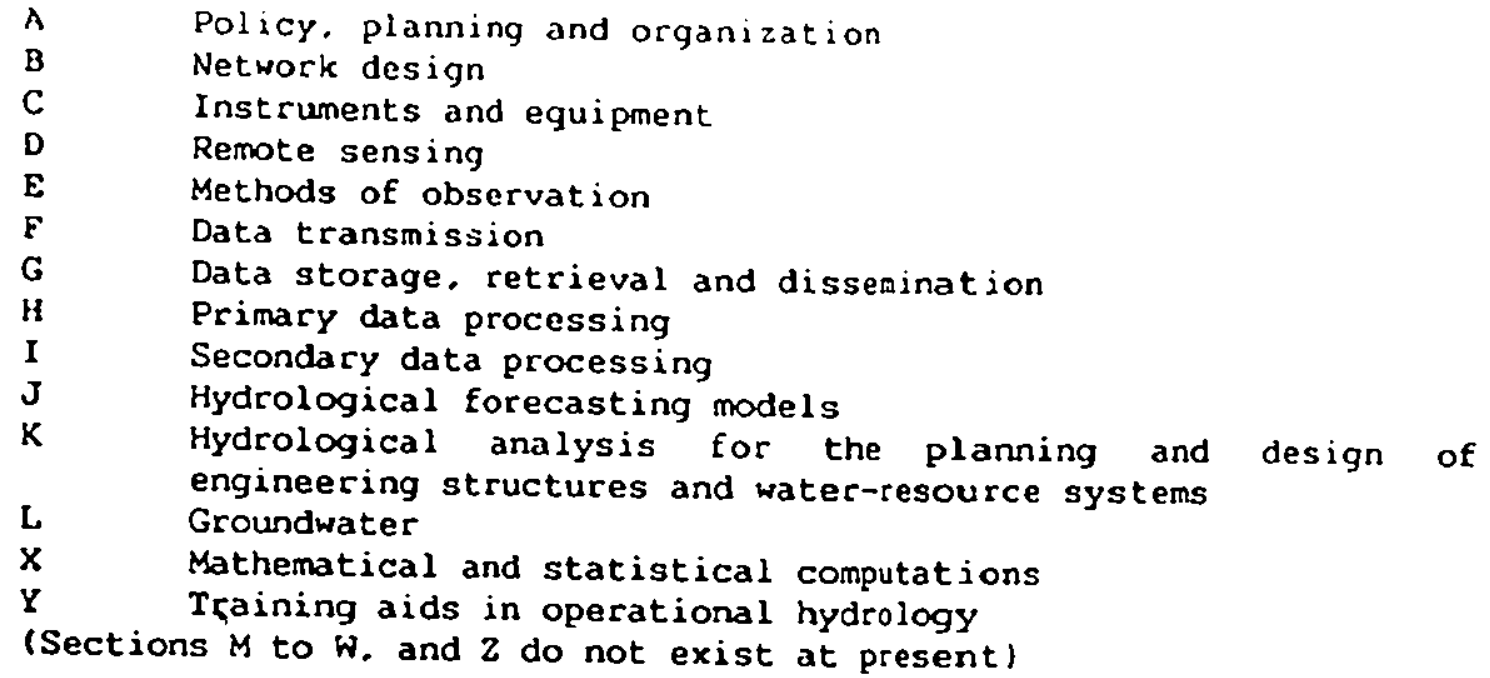

Sections are subdivided into subsections each of which is given a two digit numeric code. For example H09 denotes a subsection of section $H$ primary data processing, and happens to contain components dealing with the primary processing of sediment transport data. Annex $B$ part 2 contains the complete classification system. to the level of sections and subsections.

HOMS aims to provide components for users at all levels of development, therefore the components available must range from the simplest to the most complex. This range is reflected in the component number. Each component is assigned a level of complexity denoted by a single digit in the range 1 to 3 . Level 1 is the lowest level of complexity and contains the simplest components. Level 3 denotes the most complex components while components with level of complexity 2 are of intermediate complexity. In certain sections this concept of level of complexity was not judged appropriate and no levels of complexity have been assigned to the components in these sections. In these cases the level of complexity is shown as zero in the component number.

The component number is completed by a two digit serial number, used only to distinguish components in the same subsection and level of complexity frow each other. The complete component number is written in a form similar to the following coding:

Snn.c.xx

$S$ represents a letter (A to $L$, $X$ or $Y$ ) denoting a section, nn is a two-digit subsection number, $c$ is a one-digit level of complexity (1, 2 or 3 ), $x x$ is a two-digit serial number.

As an example note that component H09.2.10 is in section $H$, subsection HO9 of medium complexity (level 2) and has serial number 10

Annex B. part 1 shows a list of all the currently available components in component number order. This order is also the order of sections and subsections of the classification scheme. making it particularly simple to find the component or components intended. for a particular purpose. 
Annex $C$ contains the sumnary descriptions of the currently available components. Each description is written to a standard format. and is kept to a maximum. length of two pages (both sides of a sheet of paper).

The sumary description includes the following ten paragraphs:

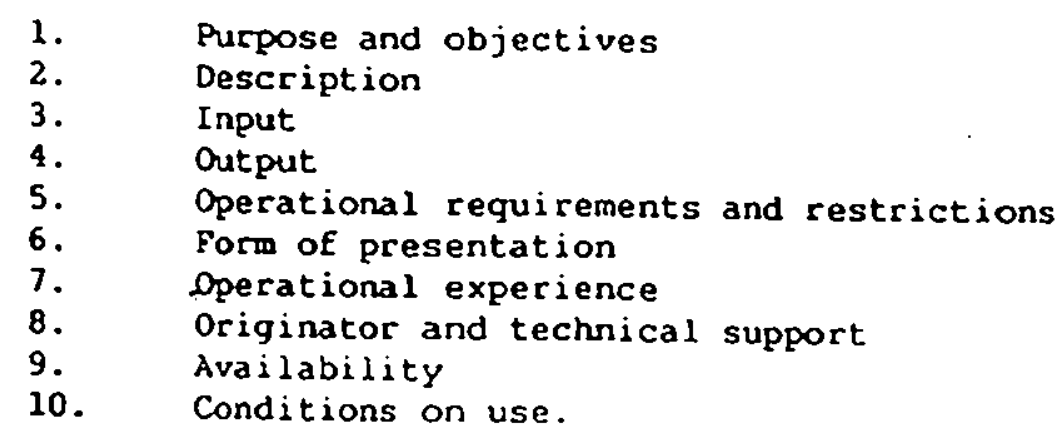

HNRCs hold a copy of the Guidelines for writing a hass component description which gives detailed instructions as to the information to be included in each paragraph. Hydrologists wishing to submit components to Hays should consult these guidelines.

\section{4 COMPATIBILITY}

HOMS has adopted a modular structure so as to be able to include a wide variety of components. On the other hand, there is a need for the components to be able to work with each other. This section of the HRM advises individuals or organizations developing potential hams components how they can meet this aim and ensure that the components they develop will be compatible with other HOSS components. It also advises prospective users of Hays components how they can determine whether the components they wish to use will be compatible both with each other and with their existing procedures and equipment.

\section{Irr.4.1 General principles}

Compatibility between components requires, among other conditions, that they meet recognized interrational standards or recommendations. WMO standards and recommendations are contained in the Technical Regulations (WNO-No. 49) and the Guide to Hydrological Practices (Who - No. 168). The International Organization for Standardization (ISO) promulgates standards in many fields and WW collaborates with ISO in fields of common interest to ensure agreement on the standards published by the two organizations. In addition. many Members have adopted their own national standards where international standards either do not exist or must be changed to meet local circumstances. Contributors of components are encouraged to develop and present components in accordance with internationally recognized standacds so that they may easily be linked with each other. 
In making the sequences in Annexes $E$ and $F$ (see also Part IV below) attention was paid to the problem of compatibility between components and therefore by selecting sequences the user can obviate compatibility problems. In other cases the user can determine whether the components he selects will be compatible with each other from the paragraphs in the sumary description dealing with input and output.

Many sequences have been submitted by Members who use them in their own operations and in these cases the components within the sequences will naturally be compatible with each other. Other sequences have been developed using components from different sources and of ten components may have had to be modified to ensure comptability with each other. In some cases this modification has been carried out by experts seconded from National Reference Centres to who to work on HOMS. In other cases users have developed compatible interfaces between components and submitted the resulting sequence.

\section{III.4.2 Compatibility of equipment}

Compatibility of instruments or equipment must satisfy two requirements: the need to interconnect instruments and the need to be able to replace an existing instrument with another either to enhance the technological level of. a system or to extend its range of applicability. These two requirements may be referred to as the interfacing problem and the replacement problem, respectively.

Interfaces are particularly important with highly complex equipment such as might be used in an automatic or telemetering system where both physical (e.g. voltage levels, impedances, plug types) and logical (e.g. signalling codes. message formats) interfaces must be carefully defined. However, the problem also arises with simpler manual instruments, where such matters as units of measurement, precision, or recording chart format should be considered. Information on these points is contained in the summary description of the component under the paragraphs on input and output.

When it is necessary to replace an instrument component with another. compatibility of function will also be required. That is to say. the new instrument must carry out the same functions as the old one but perhaps at a different level of technology or perhaps with fewer restrictions on its range of application. Information on functional compatibility is given in the paragraph on description in the summary description of the component. The paragraph on operational requirements and restrictions should also be consulted to ensure that the new instrument or equipment can operate in the environment of the existing system.

\section{III.4:3 Compatibility of software}

For components consisting of computer programs, two types of compatibility must be considered: mutual compatibility between components and compatibility of the programs with the computer systems on which they will be used. 
Generally. computer programs communicate with each other by means of files. A user who wishes to use together programs from two different components must ensure that the files reside on the same medium (disk, magnetic tape, etc.) and contain the information to be transferred in the same format. The paragraphs in the sumary description input and output, contain the information required on these points.

In determining whether a program will operate on a particular computer system, several aspects must be considered:

Programming language:

Standards are defined for the common computer languages but often manufacturers will offer extensions to the standard and these may not be the same on different computers.

- Size of memory: That is to say. the program must be able to fit into the
computer.

Peripherals requirements:

In addition to the usual magnetic disks or tapes, there may be a need for graph plotters or special displays.

- Speed of processing:

Processing time is, of course, crucial for time dependent operations such as hydrological forecasting. However, it can also be important for other applications, where a program taking a long time to run may overload the user's computer
system.

The number of bits in the computer word:

This is mainly important in its effect on the accuracy of computation, but can also cause problems with the storage of characters for titles, error messages, etc.

Interaction with the operating system:

Most program-system interactions will be handled by the compiler for the language used, but programs may also include system calls for such purposes as connecting to files. In addition. the methods of handling less common types of peripherals such as communication lines. digitizers or graph plotters, vary greatly from system to system.

Information on the operating system and on special characteristics of programs is given in the summary description under operational requirements and restrictions. The paragraph on operational experience may also indicate the computer systems on which the component has already been used. As components are used on new systems this paragraph is updated. 



\title{
Part IV. USR OR HOWS CONPPNARIS IN HYDROLOCICAL AND WATRR-RESOURCE PROJECTS
}

\author{
IV.1 HOYS SEQUENCES AND USER REQUIREMENTS
}

Though the classification system (see Part III.1) provides direct access to the components dealing with any particular subjects, many users of HOMS will not wish to approach HOMS in this manner. In general users will have sowe requirement for hydrological information and thus need some indication as to how the components of homs can be used to provide the information they require. As defined in paragraph II.1.1. guidance in the selection of components is provided by HOMS sequences and user requirements.

\section{IV.1.1 Sequences}

HOSS sequences indicate components which can be used together to satisfy some user requirement for hydrological information. The components in a sequence are all mutually compatible and can thus be used in conjunction with each other. Annex $F$ of the HRM contains the currently available sequences, while Annex $E$ is an index of these sequences in alphabetical order. Each sequence description has two parts: the first part. description, lists each of the components in the sequence, together with brief notes on its role in the sequence, while the second part. comments. describes the purpose of the sequence - the user requirement it meets - and gives notes on the application of the sequence.

When submitting new components for inclusion in HOMS, HNRCs are urged to group them in sequences wherever possible. The inclusion of components in sequences demonstrates that they can be used together and improves the systematization of HOMS.

\section{IV.1.2 User requirements}

HOMS User Requirements represent a higher level of systematization. A variety of different types of HOMS User Requirements are included in Annex $D$ of the Reference Manual.

One form of HOMS User Requirement indicates how HOMS can be used to provide information on major areas of activity in hydrology and water resources. Examples include: flood forecasting. reservoir design, or flood plain zoning. These user requirements list the sequences to be applied to provide the hydrological information required in these general areas. It will be seen that user requirements are very general in scope, and need to be amplified by reference to the descriptions of the sequences and components they coniain.

Annex $D$ also contains other advice on the selection and use of components, including sumary tables, comparing and contrasting similar HOMS components intended for application in some particular field. One example is a tabulation of the hydrological forecasting models currently available in HOMS, showing the element forecast, data requirements, and time resolution. This allows the user to quickly make a choice of model to meet his requirements. Thas form of advice supplements that given in the wo Guide to Hydrological practices or hydrological texts and is specific to the Homs components currently available. It is kept updated as new components are added or old ones deleted. 
IV. 2 SELECTION OF COMPONENTS

The HOWS Reference Manual provides three basic methods for the selection of components: Users who know exactly what they require can use the classification system to find directly the subsection of HOMS dealing with their topic. from whence they can select a component appropriate to their needs.

Users who appraach HOMS with a broader problem in mind can use sequences. For example, a hydrologist establishing a hydrological data processing system would consult HOMS sequences on primary and secondary data processing to determine the components he requires. The final choice would be made on the basis of the published component descriptions, as in the first
method above.

Finally, hoss User Requirements are available to give general guidance on the use of HOMS in operational hydrology and water resources. From the user requirements the user can turn to related sequences and components to analyze his requirements in more detail. 
ANNEX A

\title{
USST OF HOMS NATIONAL REFERENCE CENTRES AND FOCAL POINTS
}

\author{
February 1995
}

(Issued with Supplement No. 16 to the HRM)

Mail for the HOMS Office should be addressed to:

The Secretary General

World Meteorological Organization

P.O. Box 2300

1211 Geneva 2

Switzerland
Tel : + $\quad$ (4122) 7308111

Telex : 414199 OMM CH

Cable : METEOMOND GENEVA

Telefax : + 14122$) 7348250$ 



\section{ALGERIA}

Institut national des ressources hydrauliques

Cleirboic. Avo. Mohammedi, Bir Mourad Rais

Algiers

Mr. M.A. Demmak

Tol:

565415

Tolex: 62139 INRH DZ

\section{ARGENTINA}

Servicio Meteorolópico Necional

25 de Mayo 658

1002.Capital Foderal

Buenoe Aires

Sr C.A. Damboriene

Tol: $\quad+(54-1) 343.9274$ or $312.4481 / 95$

Tolatax: +(54-1) 311.3968

Tolox: 27040 METEO AR

Cable: METEOBAIRES

\section{AUSTRALIA}

Hydrology Program Office

Bureeu of Meteorology

GPO Box $1289 K$

Melbourne VIC 300

Mi Rose James

Tel: $\quad$ +(61 3) 6694608

Telefax: + (61 3) 6694725 or 6694548

Tolex: AA30434

\section{AUSTRIA}

Hydrographisches Zentralbüro

Marxergesse 2

A. 1030 Wien

The Director

Tel: $\quad+(431) 711006942$ or 32

Telefax: + (43 1) 711006851

Telex: 11,145 REGGEB

\section{BANGLADESH}

Bengladosh Water Development Board

Ispohani Building (4th Foor). 14-15, Motijheel Commercial Areo

Dhake- 1000

Mr A. Shameul Hoque, Chief Engineer, Hydrology Tol: $\quad+(880.2) 230815$

Cable: HYDROCHIEF

\section{BARBADOS}

Ministry of Agriculture

P.O.Box 505, Groeme Hall

Christ Chutch

Mr O. Cartyto Bourne

Tol: $\quad+(809) 428-3689$

Tolefax: + (809) 429.4854

Tolex: 2222 FOREIGN WB

Cable: AGMIN

\section{BELGIUM}

Inetitut Royal Mótborologique

Section d'hydrologie

3, avenue Circulaire

1180 Bruxelles

Dr F. Bultot

Tol: $\quad+(32.2) 3730611.3730545$

Telefax: + (32.2) 3751259

Telox: 21315 METEOR B

Cablo: METEOR BRUXELLES

\section{BELIZE}

Hydrology Section

Notional Meteorological Service

P.O Box 717

Belize International Airport

Mr A. Sanchaz

Tel: $\quad+(501.2) 52011,52011$

Telofax: + (591.2) 52001

Tolox: $371.211 \mathrm{CW}$ BOOTH BZ or CIVIL AIR 164

Cable: METOF BELIZE

\section{BENIN}

Direction de l'Hydraulique

Service de l'Hydrologie

B.P. 385 Cotonou

Tol: $\quad+(229) 31.34-87$ or $31-32.98$

\section{BOLIVIA}

Servicio Necional de Metoorologío y Hidrologia Avenida Camacho Esq. Bueno No. 1458, Edificio La Urbane

La Paz

Ing. Joes Cortéz $M$.

Tol: $\quad+(591.2) 326165,355824$

Tolefsx: + (591-2) 343566

Cablo: SENAHMI

\section{BRAZIL}

General Coordinator of Water Resources

Sgan, Quedra 603, Modulo J

1. Andar, Sole 103

70830-030 BRASILIA DF

Dr V. Fuzeira de St e Benevides

Tol: +\{55.61) 2255768

Tolofox: + (55-61) 2244190

\section{BRITISH CARIBBEAN TERRTORIES}

Caribbean Operational Hydrological Institute

Caribbean Moteorological Institute

Husbands, St James

Barbodos

Tel: $\quad+(1809) 4251382 / 63 / 65$

Telotax: + (1 809) 4244733

Cable: METINST BARBADOS 


\section{BULGARIA}

Inetitute of Meteorology and Hydrology

Blvd Trakia No. 66

Solis 1184

Dr D.I. Dimitrov

Tol: $\quad+(359-2) 72227175$

Telofox: + (359.2) 880380

Tolox: 22490 RTH SF/BG

\section{BURKINA FASO}

Service hydrologique

Direction de l'Inventaire des Ressources Hydreuliques B.P. 7025

Ouagadougou 03

M. Innocent Ouedraogo

Tol: $\quad+(226) 312867$ or $308035 / 36 / 37$

Telofax: $+(226) 311550$

\section{BURUNDI}

IGEBU

B.P. 331

Bujumbure

M. E. Sinarinzi

Tol: $\quad+(257) 0402318$ or 0402248 or 23150

Tolox: 3000 GITEGA

\section{CAMEROON}

Direction de la Mótborologio nationale

Service d'Hydromótborologie

c/o UNDP

B.P. 2077

Dousla

M. T. Onana Fouda

\section{CANADA}

Integrated Monitoring Brench,

Atmospheric Environment Sorvice,

Environment Conada

373 Sureex Dr., Academy LaSalle, Room E 124

Ottaws, Ontario

KIA OH3

Dr Paul J. Pilon

Tol: $\quad+(613) 9922874$

Tolefox: + (613) 9924288

Tolex: 0533188 ENV PM HULL

\section{CHAD}

Service hydrologique

Direction des Ressources on Esu et de la Mótborologie

B.P. 429

N'Djamena

M. Dj. J. Alainaye

Tet: $\quad+(235) 513043$

Tolefax: + (235) 516231

Telex: 5298 KD-ASECNA

\section{CHILE}

Dirección Goneret de Aguas

Ministerio de Ooras Públicas

Morande 59, 8 P 160

Santiago

Ing. Humberto Poño Torroalbs

Tol: $+\{56.2\} 6992233$ or 6964269

Tolofax: $+(56.2) 67266$ og or 6985341

Tolox: 24077 SETOP CL

\section{CHINA}

Ministry of Woter Rosources

Hydrological Forecesting and Water Control Conter

Pai Kwang Rosd

Beijing

Mi Lu Jiu.yuan

Tet: $\quad+(86-1) 36533)$

Telefax: + (86-1)3260635

Tolox: 22466 MWREP CN

Cable: 3048 BEIJING

\section{COLOMBIA}

Inctituto Colombiano de Hidrologia Meteorología y Adecuación de Tierres

Apartedo aereo 20032

Bogotd D.E.

Tol: $\quad+(57.1) 2860658$

Teletax: + $(57.1) 2842402$

Tolox: 44345 HIMAT CO

Cablo: HIMAT BOGOTA

\section{COMOROS}

Service métdorologique

8.P. 78

Moroni

Tel: $\quad+(269) 2313$ or 2378

Telex: 241 Public KO

Cable: METEO MORONI

\section{COSTA RICA}

Departemento de Eetudioe Bbsicos Instituto Costericense do Eloctricidad Aportedo 10032

1000 San José

Lic. Sedf Laporto $M$.

Tol: $\quad+(506) 2327309$ or 2207309

Telefax: $+(506) 2314701$ or 2314737

Tolox: CR 2140 ICE

Cable: ICE

\section{COTE D'IVOIRE}

Sous-Direction de l'hrdrologie

Direction do l'Eau

01 B.P. V 161

Abidjan

Mme Saramatou Kone

Tel: $\quad+(225) 221510$

Telex: 2108 MITRAV CI 


\section{CROATIA}

Meteorological and Hydrological Senvice

Republic of Croatia

Gric 3

4100 Zagrab

Mr Dusan Trminic, M.Sc.

Tol: $\quad+(38-41) 275689$ or 275005

Tolefax: + $(38.41) 2787.03$ or 278703

Tolex: 22233 hidro $\mathrm{hr}$

\section{CUBA}

Centro Necional de Servicio Hidrologreo Inetituto Nacional de Recursos Hidráulicos Calle Monserrate No. 213

Havans

Tol: + +(537) 622511 or 620191 or 639542

Tolofax: + (537) 335220 or $338212 / 13$

\section{CYPRUS}

Department of Water Development

Nicosia

Mr Dedalos Kyprie

Tol: $\quad+(357.2) 403521$

Tolex: 3399 MINFIN CY

\section{CZECH REPUBLIC}

Czech Hydrometoorologicel Ins titute

Na Sabatce 17

14308 Praguo - Komorany

Ing. Josef Hlodny, Deputy Directos

Tel: $\quad+(42-2) 4019780$ or 4095354

Tolefex: +(42.2) 4010800

Telox: 123335 CHMU C

Cable: HYDROMET PRAHA

\section{DEMOCRATIC PEOPLES' REPUBLIC OF KOREA}

Hydrological Research Institute

State Hydrometeorological Administration

Oesang-dong, Contral Dictrict

Pyongyang

Mi Zo Yong Chol

Tolofax: + (850.2) 814417

Tolex: 380.18 PUBLIC I KP; 380.21 TST K

\section{DENMARK}

(see Sweden)

\section{DOMINICAN REPUBLIC}

División de Hidrologia

Inatituto Nacional de Recursos Hidráulicos

Centro de los Hóroes. Apartado 1407

Sento Domingo

Ing. Jose Fco Febrillet

Tel: $\quad+(1.809) 5337000$

Telofax: + (1-809) 5324318

Tolox: 3460559

Cable: INDHRI

\section{ECUADOR}

Instituto Nacional de Moteorología - Hidrología Paris 207 y Gasper de Villaroel

Quito

Ing. Gustervo Gomez A.

Tol: +(593-2) 453035 or 248268

Cable: DIRMETECUADOR QUITO

\section{EGYPT}

Nile Control Dept

1 Sofio Zaglool St, P.O. Box EI DAWAWIN

Cairo

Mr Abdel Badio Abulhoda

Tel: $\quad+(20.2) 3541118$ or 3544204

\section{EL SALVADOR}

Servicio de Meteorología Hidrologla

Aptdo Poetal 2265

Cantón El Matasano

Soyapango

Ing. Rafeel López Vides

Tol: $\quad+(503) 770622$ oxt. 56

Telofax: + (503)770490

Cable: MINIAGRICULTURA

\section{ESTONIA}

Eetonian Moteorological and

Hydrological Instituto

Toom-Kooli 9

EEO001 Tallinn

Me Rimms Vedom

Tel: $\quad+(3722) 444190$

Tolofax: $+(3722) 441610$ or 449484

\section{ETHIOPIA}

Hydrological Service

Weter Resources Development Authority

P.O.80x 5673

Addis Ababa

Tel: $\quad+(251.1) 182942$ or 183197 
A-4

FWI

Hydrology Section (PWD)

Suva Water Supply Office

Box 3740

Samabulo, Suve

Tol: $\quad+(679) 321099$

Telefax: + (679) 320313

\section{FINLAND}

(eee Swoden)

\section{FRANCE}

Ministoro de l'Environnement

Direction de l'Eas

20. Avenus de Stour

75302 Parie $07 \mathrm{SP}$

Monejour to Diroctour do l'Eau

Attention M. Michol ODIER

Tol: $\quad+(331) 42191311$

Tolefex: + (33 1) 42191333

Tolox: 620602 DENVIR F

\section{GAMBIA}

Doportment of Weter Resources

7 Marina Parade

Banjul

Mr M.M. Soho

Tel: $\quad+(220) 228214$ or 228216

Tolofax: $+(220) 225009$

Tolox: GV 2204 SG

\section{GERMANY}

IHPIOHP Socretariat - HOMS NRC

c/o Fodoral Institute of Hydrology (Bundesenstalt für

Gewësserkunde)

Post Box 309

D.56003 Koblenz

Prof. K. Hotius

Tel: $\quad+(49261) 1306313$

Telofax: $+(49261) 1306422$

Tolex: 8.62499

\section{GHANA}

Woter Resources Research Inetitute

P.0.Box M.32

Accra

Dr Yow. Opoku.Ankomah

Tel: $\quad+(23321) 775351 / 2$

Telefax: + 23321$) 777170$

Cable: WATERSEARCH ACCRA

\section{GREECE}

Hellonic National Moteorological Sorvice P.0. Box 73502, GR 16603 Hellinikon Athens

Mr A. Niarnos

Tol: $\quad+(301) 9629415$ or 9625479

Tolofox: + (30 1) 9628952 or 9649646

Tolox: 215255

Cablo: METEOR ATHENS

\section{GUATEMALA}

INSIVUMEH

7. Ave 14-57, Zone 13

Guotemato

Ino. Sergio Hernández

Tel: $\quad+(502.2) 324722$ or 314741 or 319183

Tolotax: + (502.2) 315005

Cablo: INSIVUMEH OI GUATEOBS

\section{GUYANA}

Hydromoteorological Sonvico

Minis try of Agriculture

18 Brickdam

P.O. Box 1088

Georgetown

Mis Joyiyn Jefferally

Ted: $\quad+(592.2) 61460$ or 72463

Telofox: + $(592.2) 61460$

MINFLAM

\section{HONDURAS}

Dirección de Recureos Hidricos

Sonvicio Hidrológico y Climstológico

Apartedo Portal 1389

Tequeigalpo

Ing. Roberto Dimes Alonzo Mercado

Tol: + $\quad+(504) 336368$ or 321386 or 336361 or 32

26250

Tolofox: + $(504) 321828$

\section{HONG KONG}

Royal Observatory

134a Nathan Rd

Kowloon

Mi P. Sham, Director

Tel: $\quad+(852) 92268200$

Telefax: + (852) 7215034

Telex: 54777 GEOPH HX

Cable: OBSERVAHKG 


\section{HUNGARY}

Research Centre for Weter Resources Development (VITUKI)

H-1453 Budapest, Pf.27

Mr G. Balint

Tol: $\quad+(361) 2155001$

Telefox: $+(361) 2161514$

Tolex: $224959 \mathrm{H}$

Cable: VIZRAJZ BUDAPEST

ICELAND

(see Sweden)

\section{INDIA}

Hydrological (South) Directorate

Contral Water Commission

Sowa Bhoven, Room 513 (S), R.K. Puram

Now Delhi 110066

Mr P.D.H.S. Roo, Director

Tol: $\quad+(91-11) 606882$ or 6088855

Telox: 3166323 CWC IN

Cablo: HYDROLOGY-I CWC NEW DELHI

\section{INDONESIA}

Institute of Hydraulic Engineoring

Jin Ir. H. Juands 193

Bendung

Tol: $\quad+(62.22) 84553,84554$ or 81607

Telox: 28283 DPMA-8D

Cablo: LPMA BDG

\section{IRAN, ISLAMIC REPUBLIC OF}

Minictry of Enorgy

Water Resources Research Organization

c/o lalamic Republic of Iran Matoorological Organisation

P.O. Box 13185.461

Tohran, Mohrabad

Dr N. Rostam Afshar

Tel: $\quad+(98.21) 893566$

Telex: NIRO 273672

Cable: Ministry of Energy

\section{IRAO}

Scientific Research Council

National Committee for Hydrologr

Al-Jadiria

Baghdad

\section{IRELAND}

Dept of Engineering Hydrology

University College

Galwoy

Prof. C. Cunnane

Tel: $\quad+(353.91) 24411$

Tolefox: + (353.91) 24913

Telex: 50023 UCG EI
ISRAEL

Hydrological Sernce

P.O. Box 6381

Jeruselem 91060

Tol: $\quad+(972.2) 526201$

Tolefax: + (972.2) 520704

ITALY

Institute for Hydrogeological Protection Research in Contral Italy

National Research Council (IRPI/CNR)

Localita Madonna Alta

06100 Perugia

Tol: $\quad+(39.75) 754943 / 4$

JAMAICA

Meteorologicel Senvice

6 Hagloy Pork Plaza

Kingeton 7

Tol: $\quad+(1-809) 9261169$

\section{JAPAN}

River Plenning Division, River Bureau Ministry of Construction

2-1-3 Kosumigaseki, Chiyods-ku

Tokyo

Mr Sotoshi lyame

Tol: + $\quad$ (8i 3) 35804311

Tolofax: + (813) 52511942

\section{KENYA}

Water Development Depertment Miniotry of Wetes Dovelopment P.O. Box 3052

Nairobi

Tol: $\quad+(254-2) 716103.12$

Cable: WATER NAIROBI

\section{LATVIA}

Hydrological Department Hydrometoorological Agency

19, K. Valdemar $S t$

LV-1010 Rig.

Ms Inits Stikute

Tel: +(371-2)280424

Tolofax: + (371.2)28 6783

Tolox: 161151 


\section{LESOTHO}

Dept of Water Affairs

P.O. Box 772

Maseru

S. Makhoolibe

Tel: $\quad+(266) 325068$

Tolofax: $+(266) 350325$

Telex: 4431 LO

Cable: HYDROMET

\section{LIBERIA}

Liberia Hydrological Sonvice

Minietry of Lends. Mines and Eneroy

P.O. Box 9024

Monrovia

\section{LITHUANIA}

Lthuarian Board for

Hydrometeorology

Rudnios 6

Vilnius 2600

Mre Ona Zuksuckiend

Tol: $\quad+(370.2) 752213$ or 751194 or 754012

Telefax: + (370-2) 753500

Coble: 261240 TLG SU + LITOVGIDROMET + 303337

ORAI

\section{MADAGASCAR}

Service de la Métérologie egricole et de I'Hydrologie B.P. 1254

Antonsnerivo

Mme Chrietine Rezafy

Tol: $\quad+(261-2) 40241$ oxt. 208

Tolofax: + (261-2) 40581

\section{MALAWI}

Weter Recources Branch

Weter Department

Private Beg 390

Lilongwe 3

Mi E.Z. Laisi

Tol: $\quad+(265) 730424$ of 732155

Tolofex: $+(265) 784678$

Tolox: $4285 \mathrm{MI}$

Cable: WORKS

\section{MALAYSIA}

Drainage and Irrigation Department

Jalan Sulten Salohuddin

50626 Kuala Lumpur

Director General

Tel: $\quad+(60.3) 2982011$

Telofax: + (60.3) 2914282

Coble: DIRRIG KUALA LUMPUR

\section{MALI}

Division Hydrologie

Direction Nationalo de l'Hydraulique et de l'Energie

B.P. 66

Bamako

Tol: $\quad+(223) 224877$ or 222588

Telox: 2406

\section{MALTA}

Institute of Water Tochnolooy

Water Services Corporation

Qormi Rd

Lug. LQA O5

Mi Antoine Riolo

Tel: $\quad+(356) 249851$

Tolefax: + (356) 223016

\section{MAURITIUS}

Meteorologica Services

Vecose

Mi S.N. Sok Appadu

Tel: $\quad+(230) 6861031$ or 6861032

Tolefox: + (230) 6861033

Cable: METOR MAURITIUS

\section{MEXICO}

Instituto Mexceno de Tocnología del Agua

Paseo Cuauhnéhuac 8532. Col. Progroso, Jiutapec CP 62550 Merelos

Di Joner Aparicio

Tol: $\quad+(5273) 194049$

Tolefex: + (52 73) 194341

Telex: 4900008981

\section{MOROCCO}

Direction de lo Recherche et de le Planificetion de l'Eau Administration de I'Hydroulique B.P. Rabet-Chellah

Rabat

Mr Mohammed Jellalj

Tel: $\quad+(212-7) 778742$

Telefex: $+(212.7) 778696$

Tolex: $32876 \mathrm{M}$

\section{MOzAMBIQUe}

National Directorate of Water P.O. Box 1611

Maputo

Eng. A. Lopec Poreirs

Tel: $\quad+(258) 422191 / 92$

Telefax: + (258) 421403

Telex: 6-521 HIDR MO

Cable: HIDRAULICA Maputo 


\section{MYANMAR}

Depertment of Motoorology and Hydrology Moyangon Post Office, 11061

Yangon

Tel: $\quad+(95.1) 63390$

Tolex: 21512 BURMET BM

Cable: BAMETEORS

\section{NAMIBIA}

Hydrology Division

Depertment of Woter Affeirs

Private Bag 13193

Mr G. ven Langenthove

Tol: $\quad+(264-61) 631.41 \times 2081$

Tolofax: +264.61$) 632.22$

Tolox: 33.18

\section{NEPAL}

Hydrology Soction

Depertment of Irrigation, Hydrolooy and Moteorology

P.O. Box 3526

Kathmandu

Mr Kiran Shankar

Tel: $\quad+(9771) 212151$

Telefax: + (977 1) 521982 (via GTZ office)

Cable: HYDRONEP

\section{NEW ZEALAND}

Environmentel Dete

National Inctitute of Water \& Atmosphoric Research Ltd P.O. Box 3047

Wellington

General Manager

Tal: $\quad+(644) 4729966$

Tolofax: + (644) 4969411

\section{NICARAGUA}

Instituto Nicaraguense de Eatudios Terrestros (INETER) Apartado 2110

Manague

Ing. Claudio Gutiérrez

Tol: $\quad+(505-2) 666093$

Tolofax: $+(505-2) 663416$

\section{NIGER}

Service hydrologique. Direction des Ressourcee en Eau Ministore de l'Hydreulique ot de l'Environnement B.P. 257

Niomoy

M. Kente lbrahim

Tel: $\quad+(227) 723889$

Telefax: $+(227) 733588$

Telex: $5509 \mathrm{NI}$

\section{NIGERIA}

Department of Hydrology and Hydrogeology

Foderal Minietry of Weter Resources

P.M.B. 159, Gorki

Abuj:

\section{NORWAY}

(eee Swoden)

\section{PAKISTAN}

Pakistan Water and Power Development Authority (WAPDA)

Hydrology and Water Management Organization

236.WAPDA HouBe.

Sharah-0-Quaid-o-Azam

Lahoro

Mr Muhemmed Saleem Worsi, Chiof Engineer

Tol: $\quad+(92.42) 212668$ or $6366911 / 2236$

Tolofax: + (92.42) 413160

Tolex: 44869 WAPOA - PK

Coblo: WAPOA LAHORE

\section{PANAMA}

Depto. de Hidrometeorologia

Instituto de Recureos Hidrb́ulicos y Electrificación Apartado $\mathbf{5 2 8 5}$

Panamb

Ing. Claudia Candanedo

Tel: $\quad+(507) 621584$ or 628770

Telefax: + (507)6291 17 or 274769

Tolox: 2158 IRHE PA

Cable: IRHE

\section{PAPUA NEW GUINEA}

Bureau of Weter Resources

Dept of Environment and Conservation

P.O.Box 6580

BOROKO

Tol: +(675) 214708 of 211747

Tolox: WABPRO NE2221

\section{PARAGUAY}

Ministerio de Defenea Nacionel

Servicio Nacional de Meteorología o Hidrología

Av. Mcal. Lopez 1146, 4 Piso

Asunción

Mr Miguel A. Vazguez

Tel: $\quad+(595-21) 22139$ or 313033

Telefax: + (595-21) 212058

Tolex: 629 Py MDN 
PERU

Sorvicio Nacional de Moteorologla o Hidrologla (SENAMHI)

Direccion de Estudios Hidrológicos

Avenide Ropúblice de Chile No. 295

Lims

Ing. Luis Brea Kaik

Tol: $\quad+(51-14) 327624$

\section{PHILIPPINES}

Notional Flood Forocasting Otfice

PAGASA

1424 Quezon Averue, Q.C.

Motro Manila

Mr Cipriano C. Ferraris

Tel: Diroct $+(63.2) 9218313$ or PABX 9228401 to 19

Tolofax: $+(63-2) 9221872$ or 9247744

Tolox: 42021 PAGASA PM

Coble: 66682 WXMLA

\section{POLAND}

Institute of Meteorology and Water Managoment

Water Management Branch

ul Podloene 61

01-673 Warsaw

Mr T. Klinski

Tol: $\quad+(4822) 340708$ or 341851

Telefax: $+(4822) 341788$ or 341801

Tolox: $814331 \mathrm{hm} \mathrm{pl}$

Coble: CENTROHYDROMET WARSAW

\section{PORTUGAL}

Direçào-Geral dos Recureos aprovoitementos Hidráulicos

Divisáo de Hidrometrie

Av. Almiranto Cago Coutinho, 30-13

1000 Lisbos

Mo. M.E.V. Mocedo

Yel: $\quad+(351.1) 807551$ or 807801

Tolox: 15853 CHEIAS $P$

\section{REPUBLIC OF KOREA}

River Planning Division, Water Resources Buroau Ministry of Construction

i. Chungeng-dong, Kwacheon, Kyungpee-do 427.760

Sooul

Mr. Noh Jae Hwo

Tel: $\quad+(82.2) 5932447$ or 5037372

Telox: 24755 MOCONST $K$

\section{ROMANIA}

Inctitut de métérologie et d'hydrologie

Sos. Bucuresti-Ploiesti 97

Bucare6t 18

Tel: $\quad+(40.1) 19340$

Telefax: + $(40-1) 3129843$

Cable: METEO BUCAREST

\section{RUSSIAN FEDERATION}

State Hydrological Institute Vacilieveky leland, 2 lino 23 St Petersburg 199053

Tel: $\quad+(7812) 2133458$ or 2138984 Tolofax: + (7 812) 2131028

\section{SAUDI ARABIA}

Hydrology Division, Dept of Water Resources Development

Ministry of Agriculture end Weter

Riyadh

The Director

\section{SENEGAL}

Direction du Gónie Rural ot de I'Hydraulique Ministáre du Dóveloppement Rural et de l'Hydreulique B.P. 2041

Daker

M. Abdoulaye Sond

Tol: $\quad+(221) 321118$

Tolefox: $+(221) 321116$

Tolex: $61302 \mathrm{M} \mathrm{HYDRO}$

\section{SLOVAKIA}

Slovak Hydrometeorological Instituto

Jeeeniova 17

83315 Bratidava

Mr Boris Mindrik

Tel: $\quad+(42.7) 375730,373331$

Telefax: $+(42.7) 371192$ or 376562

\section{SLOVENIA}

Ministry of the Environmental and Regional Plenning Hydrometeorological institute of Slovenie

Vojkova ib

61000 Ljubljana

Mr. Anton Music, B.Sc.

Tel: $\quad+(38.61) 327461$ or 336028

Tolofax: + +38.61$) 320466$

Telex: 31620 MET LJ

\section{SPAIN}

Oirección General de Obras Hidrbulicos

Ministorio de Obras Públicas. Transporte y Modio

Ambiente

Paseo de le Castellana, 67

Despacho B.609

28071 Madrid

Dr Eng. Alberio Rodriguez Fonial

Tel: + $\quad$ (34) 1$) 5977617$

Telefox: + (341) 5978551 


\section{SRI LANKA}

Irrigation Department

\section{P.O.Box 1138}

Colombo 7

Mr G.T. Dharmasena

Tel: $\quad+(94-1) 581636$

Tolefax: + (94-1) 584984

Tolex: 219.98 DIRRIG CE

\section{SUDAN}

Nile Woters Depertment

P.O. Box 878

Khartoum

Mr K.A. Mohemed, Director General

Tol: $\quad+(249.11) 72409$ or 78835

Telex: 223.76 MKHNL

Coblo: MOYA KHARTOUM

\section{SURINAME}

Hydraulical Research Division

Ministry of Public Works, Tolocommunication and Building Industry

P.O. Box 2110

Paramaribo

Tel: $\quad+(597) 490963$

Tolefex: $+(597) 490939$

\section{SWAZILAND}

Water Resources Branch

Ministry of Netural Resources and Energy

P.O. Box 57

Mbabane

Mr D.M.P. Lukhele

Tol: $\quad+(268) 42321 / 22 / 23 / 24$

Telefax: + (268) 42364

Telex: 2194 WO

\section{SWEDEN}

HOMS Nordic Reference Centre

Finland, Iceland, Norwoy and Swedon)

(for Denmark,

SMHI

Folkborgsvägen

S.601 76 Norrköping

Mrs Gunlög Wennerberg

Tel: $\quad+(4611) 158000$

Telefox: + (46 11) 170207

Tolox: 64400 SMHI S

Cable: HYDROMETEOR

\section{SWITZERLAND}

Service hydrologique ef geologique national 3003 Bern

Dr Ch. Emmenegger

Tel: $\quad+(4)-31) 3247758$

Telofax: + (41-31) 3247681

Telex: 912982 LHG

\section{SYRIA}

Hoad, Surface Water Division

Ministry of Irrigation

P.O. Box 4451

Demescus

H. Eng. J. Jamal El-Din

Tel: $\quad+(963-11) 221400$

Tolox: IRIGAT $441059 \mathrm{SY}$

Cablo: RAY

\section{TAJIKISTAN}

Main Adminietration of Hydrometeorology and Emvironmental Monitoring

47. Shevchenko St

734025 Duahanbe

Mr Boris 1. Kalontarov

Tol: $\quad+(7.3372) 215291$ or 295522

Telefox: + (7.3372) 214124

Tolox: 201104 VODA

Cabio: DUSHANBE GIMET

\section{THAILAND}

Meteorological Department

4353 Sukumvit Road

Bang Na, Phrakanong

Bengkok 10260

Mr Siriboon Lekplipol

Tel: +(66-2) 3989868

Tolofax: + (66.2) 3994014

Tolex: 72004 DEPMETE TH

Cable: METEOR BANGKOK

\section{TRINIDAD \& TOBAGO}

Weter Regources Agency

P.O. Box 145

Port-of Span

The Director

Tel: $\quad+(1809) 6278277$ or 6278278

Cable: WASA

\section{TUNISIA}

Instutut National de la Metborologie

Sous-Direction de la Mbtéorologie bconomique

B.P. 22

2035 Tunis-Carthage

M. A. Kasear

Tel: $\quad+(216.1) 287400$

Tolox: 12369

Cablo: METUNIS

\section{UGANDA}

Department of Metcorology

P.O. Box 7025

Kampala

Tel: $\quad+(256.41) 258572$ or 258537 or 253559

Toletex: + (256-41) 251797

Telex: +61061 
A-10

\section{UNITED KINGDOM}

Inetitute of Hydrology

Macloan Building

Crowmarsh Gifford

Wollingtord, Oxon OX10 88B

Dr H.R. Oliver

Tol: $\quad+(44) 491) 838800$

Tolofox: $+(44) 491.672424$

Tolox: 849365 HYDROL G

Coble: HYCYCLE

\section{UNTED STATES}

Office of Hydrology, SSMC.2

National Woather Servico, NOAA

Room 8144. 1325 East.Wost Highway

Silver Spring. MD 20910

Mr E.A. Stellings

Tol: $\quad+(1.301) 7130006$

Tolefex: + $11-301)>130963$

Tolox: vio RCA-248376 OBSWUR, vis TRT. 197683

KWBC UT

Coblo: WNOAA WASHDC

\section{URUGUAY}

Minieterio de Trensporte y Obres Públices

Dirección Nocional de Hidrografía

Rincón 575, piso 2.

Cesille de Corroo 413

Montovideo

Ing. G. Arduino

Tol: $\quad+(598.2) 964784$

Tolofox: $+(598-2) 964667 / 2883$

\section{UZBEKISTAN}

Main Adminictration of Hydrometeorology

72. Observatorskaya St

Tashkent 700052

Dr Anstoliy Ovchinnikov

Tel: $\quad+(7-3712) 336180$ or 320758

Tolofox: $+(7.3712) 332025$

Telox: 116573 UZMET

Cable: TASHKENT GIMET

\section{VANUATU}

Hydrology Section

Geology, Mines and Water Resources

Private Mail Bag 1

Port Vila

Tol: $\quad+(678) 22423$ or 223246

Telofax: + (678) 22213

Tolex: 1040 VANGOV NH

\section{VENEZUELA}

Dirección de Hidrología y Metoorologja MARNR

Edificio Camojo, piso 5

Caracas

Ing. Claudio Caponi

Tol: $\quad+(582) 4081601 / 02$ or 5814364

Tolofax: +(582) 5418375 or 5450607

Telox: 28475 MARNR VC

\section{VIETNAM}

Service hydrometto orologique

4 Dang Thai Than St

Hanoi

Tel: $\quad+(844) 253343$ or 253467

Telefax: + (84-4) 260779

Cable: HYOROMETEO HANOI

\section{YEMEN}

General Directorate of Irrigetion, Department of Water Ministry of Agriculture and Fisheries P.O. Box 2805

Sana'o

Mr Mohammed Saad Harmal

\section{YUGOSLAVIA}

Foderal Hydromoteorological Institute Bircaninove 6. P.O. Box 604 11001 Belgedo

Dr Mihailo Andjolic

Tol: $\quad+(38.11) 646445$ or 645779

Tolofax: + $(38-11) 646369$

Telex: 11141 YU HIDRO of 12937

Cablo: HYOROMETEOR BELGRAD

\section{ZAMBIA}

Weter Resources Research Unit National Council for Scientific Rocearch P.O. BOX CH 158

Lusaka

Mr C.8. Mwasilo

Tol: $\quad+(260-1) 281081$

Cable: NACSIR, Chelston, Lusako

\section{ZIMBABWE}

Hydrology Branch

Division of Water Department

P Beg 7712, Couseway

Herere

Mir G. Mawere

Tel: $\quad+(263.4) 707861$

Telex: 221412 IM-GOV-ZW 
HOMS REGIONAL FOCAL POINTS

\section{AGRHYMET}

Centro régional de Formation on Agromb́tborologie of Hydrologie opórationnelle

B.P. 11011

Niamey

NIGER

Directeur Góndrel

Tol: $\quad+(227) 733136,732436$

Tolofax: + (227) 732435

Coble: AGRHYMET Niamoy

Tolox: $5448 \mathrm{NI}$

\section{AIT HOMS FOCAL POINT}

Asian Institute of Tochnology

P.O. Box 22754

Bangkok

THAILAND

Di Nicanor C. Austriaco

Tol: $\quad+(66.2) 5290100-13$ or 5290091.3

Cablo: AIT BANGKOK

Tolex: 84276 AIT TH

\section{ARAB STATES FOCAL POINT}

The Arab Centre for the Study of Arid Zones and Dry Londe (ACSAD)

P.O. Box 2440

Damascus

SYRIAN ARAB REPUBLIC

Di Jean Khouri

Tol: $\quad+(963.11) 755713$ or 755714

Telofox: 96311755712

Coble: ACSAD

Tolex: 412697 ACSAD SY

\section{CENTRAL AMERICAN ISTHMUS FOCAL} POINT

Comite Regional de Recursos Hidtóblicoe (CRRH) Apartado 3514.1000

San Jose

COSTA RICA

Lic Eladio Zarate $H$.

Tel: +(506) 315791

Telox: 3651 COMITE CR

COMITE INTERAFRICAIN D'ETUDES HYDRAULIOUES

01 BP 369

Ouagadougou 01

BURKINA FASO

Tel: $\quad+(226) 307112$ or 307115

Tolox: 5277 BF

\section{EAST AFRICAN DROUGHT MONITORING PROJECT}

Drought Monitoring Centro

P.O. Box 30259

Nairobi

KENYA

Mr J.M. Maina

Tol: +(254-2) 567880

Cablo: WEATHER NAIRO8

Tolox: 22208

\section{HYDRONIGER}

Centre International de Próvision

B.P. 10377

Niamey

NIGER

Tel: $\quad(+227) 7332.39$ or 734389

Telex: $\mathbf{5 3 2 8}$

MEKONG HOMS FOCAL POINT

Mokong Secrotariat

Kaosteuk Bridge, Rama I Road

Bangkok 10330

THAILANO

Mr Pechern Sridurongketum, Otficer-in-Charge.

Hydrology Unit

Tol: $\quad+(66-2) 2250029$

Telefox: +(66-2) 2252896

Cable: MEKONG BANGKOK

Tolex: 21322 MEKONG TH

\section{UPPER NILE FOCAL POINT}

Hydrometeorological Survey of Lokes Victoria, Kyoge and Mobutu Sere Soko

P.0. Box 192

Entebbo

UGANDA

Eng. E.A. Oryang

Cable: HYOROMET 



\section{ANNEX B}

\section{LIST OF HOMS COMPONENTS}

(Issued with Supplement No. 16 to the HRM)

Part 1 of this annex gives a classified list of currently available HOMS components by section and subsection.

Part 2 of the annex gives the complete classification scheme for HOMS components. 

SECTION A POLICY, PLANNING. AND ORGANISATION.

A00.0.01 Casebook of examples of organization and operation of hydrological services

A00.0.02 Hydrologists safety manual

AO0.0.03 Guide on the maintenance of streams

A00.0.04 Policy on services for communications and archiving of data from automatic stations

A00.0.06 Assessment of water resources

\section{SECTION B NETWORK DESIGN.}

B00.0.02 Rationalization of a raingauge network

B00.0.03 Reference manual on the planning of meteorological observation networks

BO0.0.04 Climatological network design using optimum interpolation

B00.0.06 A hydrometrically orientated station numbering system

B00.0.07 Optimization of surface water level gauging networks

\section{SECTION C INSTRUMENTS AND EQUIPMENT.}

COO GENERAL

C00.1.02 Hydrometric equipment handbook

C00.1.04 Manual for the design construction and inspection of hydrometric stations

C00.2.02 Reading 16 track punched tape

C00.2.03 In situ data logger

C00.2.06 Memory card type data processing and recording system

C00.3.02 Specifications for solid state memory recorders

C00.3.03 Measuring systems and interfaces for recording hydrological data

C00.3.05 Precision turbidity recording meter

\section{CO9 SEDIMENT LOAD}

C09.2.01 Hydrographic data acquisition system, HYDAC

\section{C10 SUSPENDED LOAD}

C10.1.01 US DH-48 suspended sediment sampler

C10.1.02 US DH.76 suspended sediment sampler

C10.1.03 US D-74 suspended sediment sampler

C10.2.01 US P-61 suspended sediment sampler

C10.2.02 US P-63 suspended sediment sampler

\section{C12 BED LOAD}

C12.1.01 Chanjang bed-load sampler

C12.2.01 US BMH-53 bed-material sampler

C12.2.02 US BMH-60 bed material sampler

C12.2.03 US BM-54 bed-material sampler

\section{C25 GENERAL METEOROLOGICAL DATA; CLIMATE AND WEATHER STATIONS}

\section{C25.3.03 Automatic weather station}


B.1.2

C27

PRECIPITATION, MANUAL \& STORAGE GAUGES

C27.1.02 Manual raingauge

C27.1.03 Daily rain gauge

C30 PRECIPITATION, RECORDING AND TELEMETERING GAUGES

C30.1.01 Rain gauge for mountain areas (Ombrograph)

C30.1.02 A simple low cost reliable raingauge

C30.2.01 Rainfall alarm

C30.2.04 Siphoning 31 day raingauge

C30.2.05 Long duration recording precipitation gauge

C30.2.06 180-day rainfall recorder

C30.3.01 ALERT rain gauge

C30.3.03 Rainfall intensity recording and archiving system

C33 PRECIPITATION, MEASUREMENT BY RADAR

C33.3.01 Radar raingauge system

\section{C35 AIR TEMPERATURE}

C35.1.01 Double-louvered thermometer screen

C46 EVAPORATION, PANS AND TANKS

C46.1.02 Evaporation pan

C46.1.03 Class A evaporation pan

C58 SOIL MOISTURE, NUCLEAR METHODS

C58.3.01 Neutron probe for soil moisture measurement

C60 SOIL MOISTURE, ELECTRICÁL METHODS

C60.3.01 Dielectric measurement of the soil water content

C60.3.02 Capacitance probe for measuring soil moisture

C62 SOIL MOISTURE, TENSIOMETERS

C62.3.01 Pressure transducer soil tensiometer

C62.3.02 Tensiometers for measurement of soil water pressure

C65 GROUNDWATER, LEVEL

C65.2.01 Electrical contact water level gauge

C67 GROUNDWATER, BOREHOLE LOGGERS

C67.1.01 Observation well for sea water-fresh water interface

\section{C71 WATER LEVEL OR STAGE}

C71.1.02 HOMS Catalogue of water level recorders

C71.3.01 ALERT river level (float-type) station

C71.3.02 Water-level recorder with removable static memory

C71.3.03 Pressure probe for water level measurement

C71.3.08 Precision water level recording gauge 
C73 STREAM DISCHARGE, Flumes, WeIRS, ULTRASONIC, AND ELECTRO-MAGNETIC METHODS

C73.3.01 Acoustic flow meter

C79 WATER VELOCITY, CURRENT METERS OR FLOATS

C79.1.02 HOMS Catalogue of current meters

C85 RIVER GAUGING, GENERAL

C85.1.01 Gauging vehicle

C85.1.02 HOMS Catalogue of winches, cranes, cableways, and other gauging accessories

C86 RIVER GAUGING, CABLEWAYS

C86.1.01 Overhead float thrower

C86.2.01 Technical standard for measuring river flow and sediment by hydrometric cableway

C88 RIVER GAUGING, CRANES, BRIDGE FRAMES, WINCHES, AND REELS

C88.1.01 Portable river gauging winch

\section{SECTION D REMOTE SENSING.}

D00.0.01 Application of remote sensing to operational hydrology

D00.0.03 Water surface temperature mapping from satellite

D00.0.04 Assessment of snow amount on river catchments by means of satellite data

D00.0.05 Airborne radiometer temperature surveys

D00.0.07 Snow cover from multi-channel satellite data

DO0.0.08 Surface water temperature from polar-orbiting satellite infrared data

D00.0.09 Photo interpretation and mapping of flood-prone areas

D00.0.10 Estimation of extent of flooding using satellite images

DO0.0.11 Estimation of the polluted area of snow cover around towns using satellite images

D00.0.12 Mapping of river floods using satellite images and digital image processing

DO0.0.13 Determination of icing conditions on large lakes using satellite images

DO0.0.14 Satellite image interpretation system (SIADIS)

SECTION E METHODS OF OBSERVATIONS.

EOO

GENERAL

E00.1.02 Hydrological observation explained in pictures

EO5 WATER QUALITY

E05.1.01 Guidelines for sampling surface water quality variables

E05.1.04 Water quality sourcebook

E05.2.02 Sampling for water quality

E05.2.03 Water quality analytical methods manual 1979

E09. SEDIMENT

E09.2.01 Field methods for measurements of fluvial sediment

E09.2.02 Sediment surveys

E09.2.03 Manual on sediment transport measurements

E09.2.04 Fluvial sediment concepts 
E25.1.01 Meteorological observations for hydrological purposes

E25.1.03 Organization of observations of evaporation on evaporimeters and evaporative reservoirs

E25.1.04 AES guidelines for co-operative climatic autostations

\section{E53 SNOW AND ICE, GLACIOLOGY}

\section{E53.1.04 Snow survey}

E55 SOIL MOISTURE

E55.2.01 Use of the neutron probe for soil moisture measurement

\section{E65 GROUNDWATER}

E65.1.01 Systematic observation of the main subsurface water characteristics

E65.1.02 Sampling groundwater for hydrogeological investigations

E65.2.01 Determination of water table depth by hammer seismic refraction

\section{E7O SURFACE WATER, LEVEL AND FLOW}

E70.1.02 Manual on procedures in operational hydrology, volume I-V

E70.1.05 Graphical ice correction

E70.1.06 The instrumentation of flat low-lying catchments

E70.2.01 General field and office procedures for indirect discharge measurements

E70.2.02 Measurement of peak discharge by the slope-area method

E70.2.03 Measurement of peak discharge at culverts by indirect methods

E70.2.04 Measurement of peak discharge at width contractions by indirect methods

E70.2.05 Circulation studies using fluorescent dyes

E70.2.06 Measurement of peak discharge at dams by indirect methods

E70.2.07 A guide to slope-area discharge gauging in mountain rivers

E70.2.08 Manual for wáter gauging and discharge measurement

E70.3.01 Software Q: A program package for evaluating and managing discharge data on DOS computers

\section{E71 WATER LEVEL}

\section{E71.1.02 Measurement of stage}

\section{E73 DISCHARGE MEASUREMENT, DILUTION GAUGING}

E73.2.01 Method for discharge measurement with dye tracing techniques

E73.2.02 Fluorometric procedures for dye tracing

E73.2.03 Measurement of time of travel and dispersion in streams by dye tracing

E73.2.04 Determination of stream reaeration coefficients by use of tracers

E73.2.05 Measurement of discharge using tracers

\section{E79 VELOCITY MEASUREMENTS, USE OF CURRENT METERS}

E79.1.01. Two-point method of measuring discharge velocity

E79.1.02 Correction of observed depth for angle of sounding line

E79.1.03 Technique of stream gauging by current meter

E79.2.06 Discharge measurement by moving boat method 
E88.1.01 Levelling

\section{SECTION F DATA TRANSMISSION.}

F00.1.06 Flood warning device

F00.2.01 Telephone service water level gauge

F00.2.06 Flood warning system

F00.2.09 Satellite data collection platform

F00.2.13 Telemetering station land radio link

F00.2.15 Satellite direct readout ground stations

F00.2.17 DATAPOST - PC program for data collection

F00.3.01 Data collection and transmission system (Ott Allgomatic)

F00.3.02 River information system

Fo0.3.04 Automatic network for collecting real-time hydrological data

FO0.3.05 ALERT data collection substation

F00.3.06 System for recording and transmitting rainfall data

F00.3.07 Modular system for recording and transmitting hydro-climatological data

Fo0.3.08 Telemetry system for data acquisition and flood forecasting

FO0.3.09 Data collection platform (DCP) specifications

F00.3.10 The telemetry of hydrological data by satellite

F00.3.13 Telemetering system

\section{SECTION G DATA STORAGE, RETRIEVAL AND DISSEMINATION.}

\section{G05 STANDARDS, MANUALS AND RECOMMENDATIONS}

G05.2.03 Data storage, retrieval and transmission data archival formats

\section{G06 SYSTEMS FOR STORING GENERAL HYDROLOGICAL DATA}

G06.2.01 Software for archiving and retrieving time-dependent data (TIDEDA)

G06.2.03 HYDSYS - time series data management software

G06.2.04 Automatic data quality-control and analysis system (SYSCAD)

G06.3.01 Storage and file management system for hydrological data (main frame version)

G06.3.01 Database management software for hydrological data (micro computer version)

G06.3.02 HYDATA - hydrological database and analysis system

G06.3.03 Management system for field data (FIELDMAN)

G06.3.04 HYMOS: database management and processing system: for hydro-meteorological quality and quantity data

\section{G08 SURFACE WATER OR RIVER DATA STORAGE SYSTEMS}

G08.2.03 Hydrometric and sediment date banks

G08.2.04 Computer storage of hydrological data from rivers.

G08.2.05 Methods and software for establishing and maintaining a data base

G08.2.06 Hydrometric data base

G08.2.07 HYDROM: Hydrometric data management software

G08.3.01 Data storage and file management for mean daily discharges

G10 GROUNDWATER DATA STORAGE SYSTEMS: LEVELS, WATER CHEMISTRY, WELL YIELDS AND FLOWS

G10.3.01 Ground water information system

G10.3.02 Groundwater information processing system (GRIPS) 
G12.2.01 Synoptic data processing package

G12.2.02 PLUVIOM: Precipitation data management software

\section{G14 WATER QUALITY DATA STORAGE SYSTEMS}

G14.3.02 HYQUAL - Water quality database

G20 GENERAL HYDROLOGICAL DATA TABULATION PROGRAMS

G20.2.01 Printout of data stored in working files

G30 INFORMATION OR DATA DISSEMINATION SYSTEMS

G30.2.01 Hydroinform: minicomputer controlled automatic hydrologic information dissemination unit

G40 TRANSFER OF DATA BETWEEN AUTHORITIES, STANDARDS, RECOMMENDATIONS, MANUALS AND METHODS OF CODING

G40.2.01 Standards for interchange of water resources data

SECTION H PRIMARY DATA PROCESSING.

HOO SYSTEMS PROCESSING SEVERAL TYPES OF DATA

H00.1.02 Area, length, point location processing program records

H00.3.01 Operational hydrometeorological data processing

HO5 GENERAL WATER QUALITY DATA

H05.2.01 Guidelines for the primary processing of surface water quality data

HO6 WATER TEMPERATURE DATA

H06.2.02 Water temperature data processing program (analogue recording gauge)

HO9 SEDIMENT TRANSPORT DATA

H09.1.01 Computation of fluvial sediment discharge

H09.1.03 Method of determining bed load runoff from available data

H09.2.01 Suspended sediment computations

H09.2.02 Analysis of suspended sediment measurements

H25 GENERAL METEOROLOGICAL DATA FOR USE IN HYDROLOGY

H25.1.02 Primary manual data processing of meteorological observations for hydrological purposes

H25.3.01 Decoding of synoptic reports to extract hydrometeorological information

H26 PRECIPITATION DATA, NON-RADAR

H26.2.01 Reduction and use of 10 minute precipitation observations

H26.2.02. Long duration recorded precipitation data processing system

H26.2.03 System for digitizing chart recorded rainfall data 
H39.2.01 Calculation of various indicators of air humidity

H55 SOIL MOISTURE DATA

H55.2.02 Soil water information processing system

\section{H7O SURFACE WATER (LEVEL AND FLOW) GENERAL}

H70.1.02 Primary manual data processing of surface water characteristics

H70.2.05 Hydrometric data processing program (manual gauge)

H70.2.06 Hydrometric data processing program (analogue recording gauge)

H70.2.07 Automatic primary processing and checking of hydrological data

\section{H71 WATER LEVEL DATA, RIVER STAGE, LAKE OR RESERVOIR LEVELS}

H71.2.04 System for digitizing analogue recorded water-stages

H71.2.06 Digitizing and computer storage of water levels in tidal areas

H71.2.07 System for digitizing hydrological recorder charts

\section{H73 DISCHARGE DATA, ALL RANGES}

H73.3.01 Flow estimation by interactive graphic and flood routing techniques

H73.3.05 Computation of discharge by the slope-area method

H76 DERIVATION OF RATING CURVES, CONVERTING STAGE TO FLOW BY MEANS OF RATING CURVES

H76.2.01 Mathematical calculation of the rating curve (stage-discharge equation)

H76.2.02 Multi-variable rating curve (QTOBBV)

H76.2.03 Determining daily mean discharges using the rate of change in stage

H76.2.04 Calculation of discharge by means of stage-discharge analytical relations (main frame version)

H76.2.04 Calculation of discharge by means of stage-discharge analytical relations (micro computer version)

H76.2.05 Discharge ratings at gauging stations

H76.2.06 Computation of continuous records of streamflow

H76.2.07 Stage-discharge relations at culverts (SWCULRAT)

H76.3.02 Analytical fitting of the stage-discharge relation (main frame version)

H76.3.02 Analytical fitting of the stage-discharge relation (micro computer version)

H76.3.03 Numerical fitting of stage/discharge and stage/slope/discharge relations: BASIC programs for a PC

H76.3.05 Rating curve computation (SCADE)

H76.3.06 Automatic processing of discharge measurements and computation of the stage-discharge equation

H79 WATER VELOCITY DATA, COMPUTING DISCHARGE FROM POINT VELOCITY MEASUREMENTS

H79.1.07 Current meter measurements of streamflow using the two point method

H79.1.08 Calculation of discharge from current-meter velocity measurements

H79.1.09 Current meter measurement of stream flow using the five point method

H79.2.02 Simplified discharge measurement and computing method

H79.2.05 Computation of discharge measurements

H79.3.01 Computer program for stream gauging data processing

H79.3.02 CUMEC . PC program for current meter measurements 
B-1.8

H83

PROCESSING OF HISTORICAL FLOOD INFORMATION

H83.1.01 Collection and processing of historical flood data

SECTION I SECONDARY DATA PROCESSING.

100 GENERAL

100.1.01 Recommendations for data processing for representative basins

100.1.02 Statistical analysis of long time series of hydrological data

- 100.2.01 Statistical analysis of the monthly values of a hydrological variable (main trame version)

100.2.01 Statistical analysis of the monthly values of an hydrological variable (micro computer version)

100.2.02 Annual regime of a hydrological variable

100.3.01 Hydrographical data analysis package (HYDAP)

\section{WATER QUALITY DATA}

105.2.01 Evaluation of surface water quality data and water quality maps

109 SEDIMENT TRANSPORT DATA

109.2.01 Calculation of the annual distribution of sediment runotf from available data

109.3.01 The correction to the annual load of measured suspended sediment

\section{PRECIPITATION DATA}

126.1.01 Tabulation of rainfall series and selection of storms

126.1.02 Regional distribution of point rainfall intensities

126.1.03 Computation of rainfall return period values by Gumbel's method

126.1.04 Rainfall probability processing program

126.1.05 Computation of rainfall return periods by partial duration series

126.1.06 Mean areal precipitation by triangular grids

126.1.07 Analysis of digitized raingauge records

126.2.01 Daily average areal precipitation by the Thiessen method (main frame version)

126.2.01 Daily average areal precipitation by the Thiessen method (micro computer version

126.2.03 Storm areal averages by fitting polynomials

126.2.05 Rainfall data processing (CORDA)

126.3.01 Computer drawn areal rainfall and averaging

126.3.02 Checking and areal analysis of precipitation data (SVARD)

126.3.03 Mean areal precipitation (NWSRFS-MAP)

\section{I36 AIRBORNE POLLUTION}

136.3.01 Precipitation chemistry - small-grid regional sulphur deposition model

136.3.02 Regional sulphur deposition model

145 EVAPORATION, GENERAL

145.1.03 Computing shallow lake evaporation using Class A pan data 
150.2.01 Calculation of free water surface evaporation by the Penman method

150.2.02 Potential evapotranspiration from vegetation by the energy balance method

150.2.03 Catchment potential evapotranspiration by the energy balance method

150.2.05 Computation of actual evaporation using a composite method

150.2.06 The heat and water balance method of calculating actual evaporation

150.2.07 Potential evapotranspiration by Penman's method

\section{SNOW DATA}

153.2.01 Objective analysis of the water equivalent of snow cover

160.2.01 Calculation of areal evaporation and soil moisture deficit

\section{DISCHARGE DATA}

173.1.02 Frequency curves

173.1.03 Duration curve (CURDURA)

173.1.04 Verification of mean discharges over the river network

173.1.05 Verification of extreme annual discharges over the river network

173.1.07 Discharge-duration-frequency curves

173.1.08 Volume-discharge-frequency curves

173.2.01 Curves of ranked discharges

173.2.03 Secondary processing of monthly discharge series

173.2.04 Identification of characteristic discharges (from multi-year series of daily discharges)

173.2.05 Identification of flood (or low-flow) events and associated characteristics

173.2.06 Statistical analysis of the duration and volume of floods (or low flows)

173.2.08 Extending monthly flow series (EXTMIN)

173.2.09 Annual runoff computation with or without observational data

173.2.10 Methods for extending runoff series

173.2.12 Model for filling and extending monthly discharge series $(\mathrm{MCL})$

173.3.01 REMUS : Reconstitution of missing data by regression

\section{LOW FLOWS}

180.2.01 Statistical analysis of low flow periods

180.2.02 Calculation of annual minimum discharges with given probabilities

180.2.03 The low flow frequency analysis package (LFA)

\section{FLOODS AND FLOOD FREQUENCY ANALYSIS}

181.1.01 Program for flood peak separation

181.1.02 Recommendation for the estimation of flood-frequencies

181.1.04 Frequency of peak discharges in an arid river

181.1.09 Flood frequency analysis, program FDRPFFA

181.2.01 Statistical analysis of flood discharges

181.2.02 The consolidated frequency analysis (CFA) package

181.2.03 Flood flow frequency analysis

181.2.04 Calculation of annual maximum discharges with given probabilities

181.2.05 HFA: Hydrological frequency analysis

181.2.08 Annual flood frequency analysis (PEAKFQ) 
Models and procedures whose main purpose is the operational forecasting of various hydrological elements

\section{JO4 FORECASTING STREAMFLOW FROM HYDROMETEOROLOGICAL DATA}

J04.1.01 Tank model

J04.1.04 Snowmelt-runoff model (SRM)

J04.1.05 Inflow-storage-outflow (ISO) function models

J04.1.06 Micro-computer based flood forecasting system

J04.1.07 Operational estimation of snow cover development and snowmelt

J04.2.01 A conceptual watershed model for flood forecasting

J04.2.02 Conceptual watershed model (the HBV model)

J04.2.03 Model to forecast rainfall floods

J04.2.04 Model for the calculation of snow-melt and rainfall runoff

J04.2.05 Method for short-term forecasts of discharges in mountain rivers

J04.2.06 Short-term forecasts of spring inflow to reservoirs on plainland rivers

J04.2.09 NLC rainfall-runoff model

J04.2.10 The soil moisture accounting and routing model (SMAL)

J04.3.01 Sacramento soil moisture accounting model (NWSRFS-SAC-SMA)

J04.3.02 Sacramento model modified for use in the upper Nile basin project

J04.3.03 Snow accumulation and ablation model (NWSRFS-SNOW-17)

J04.3.07 Synthesized constrained linear system (SCLS)

\section{J10 STREAMFLOW ROUTING FOR FORECASTING}

J10.1.01 Flood peak forecasting by a grapho-analytic technique

J10.1.02 Gauge relations for flood peak forecasting (FLOODSYS)

J10.1.03 River station selection for forecasting

J10.2.01 Real-time adaptive hydrological prediction ("self-tuning predictor" algorithm)

J10.2.02 Method of unsteady flow calculation in braided river beds

J10.2.03 Flood routing using a discrete linear cascade model

J10.3.01 Hydrodynamical river model (DC2)

J10.3.02 Recursive river flow forecasting using a Kalman filter

J10.3.03 Flood routing by a linear systems analysis technique

J15 COMBINED STREAMFLOW FORECASTING AND ROUTING MODELS

J15.1.01 The linear perturbation model (LPM)

J15.2.01 Streamflow synthesis and reservoir regulation (SSARR)

J15.2.02 Nonlinear cascade hydrological model (NONLIN)

J15.2.03 CLSX (constrained linear system extended) model

J15.3.01 Manual calibration program (NWSRFS-MCP3)

J15.3.02 Multipurpose unsteady flow simulation system (MUFSYS 3)

J15.3.03 Real time streamflow forecasting model (MISP)

J15.3.05 Micro computer modelling package for real-time flood forecasting (MIKE 11 FF)

J15.3.07 Conceptual watershed model for real time forecasting of runoff

J22.1.01 Seasonal forecast of inflow to a lake

J22.1.02 A method to forecast the spring flood volume

J22.2:01 Forecasting inflows to a lake

J22.3.01 Kalman filter empirical fitting (KFEF) 
J45.2.01 Formation and melting of ice on surface waters

J45.3.01 Numerical river ice model

FORECASTING SURFACE WATER QUALITY

J55.3.01 Integrated quantity and quality snowcover formation model (ISCF) 180 ANALYSIS OF MODEL PERFORMANCE

J80.1.01 Model result analysis by the methods of the WMO model intercomparison

J80.3.01 Statistical summary - mean daily discharges (NWSRFS-STAT-OME)

SECTIONK HYDROLOGICAL ANALYSIS FOR THE PLANNING AND DESIGN OF ENGINEERING STRUCTURES AND WATER-RESOURCE SYSTEMS

Models and procedures whose main purpose is hydrological analysis for planning, development, design, and management of water-resource systems, including studies of climatic change and man's influence.

K10

\section{REGIONAL ANALYSIS}

K10.1.01 Evaluation of water resources in a country

K10.1.02 Determining surface water resources for semi-arid and arid basins without data

$\mathrm{K}$ 10.1.03 Peak discharge frequency in an arid region

K10.2.01 Resource information and analysis using grid cell data banks

K10.2.02 Long-term mean values of watershed water balance (program "RASTER")

K10.2.03 Computer programs for evaluation of regional flood risk

K10.2.04 Regional analyses of streamflow characteristics

K10.2.05 Regionalization of flow duration curves (REGFLOW)

K10.2.06 Reservoir flood estimation

\section{K15 SITE-SPECIFIC FLOOD STUDIES}

K15.1.01 Design flood estimation using historical flood data in frequency analysis

K15.1.02 Methods for computing design floods

K15.1.04 Hydrologic and hydraulic procedures for flood plain delineation

K15.2.01 Techniques for estimation of probable maximum precipitation

K15.2.02 Expected annual flood damage computation (EAD) (761-X6-L7580)

K15.2.03 Nonlinear threshold model (NTM)

K15.3.01 Damage reach stage-damage calculation (DAMCAL)

K15.3.02 Dam-break flood model (DAMBRK)

\section{K22 RAINFALL-RUNOFF SIMULATION MODELS}

K22.1.01 Runoff calculation by the storage function method

K22.1.02 Chart method for determining peak discharge

K22.1.03 Tabular method for determining peak discharge

K22.1.04 Computer program for project formulation structure site analysis (DAMS2)

K22.1.06 Engineering field manual for soil and water conservation practices

K22.1.07 Graphical method for determining peak discharge

K22.1.08 Synthetic generation of flows for river basins without data (SOIL)

K22.1.09 Morphometric unit hydrograph (UNIMORF)

K22.1.10 The unitgraph lumped technical review and analysis model (ULTRA) 
K22.2.01 Runoff model for cultivated soils

K22.2.02 Flood hydrograph package (HEC-1)

K22.2.03 Semi-conceptual watershed model

K22.2.04 Estimation of the unit hydrograph and correction of net rainfall time distribution

K22.2.05 Rainfall-runoff model for medium-sized urban basins

K22.2.06 Hydrologic parameters (HYDPAR)

K22.2.07 Aggregated runoff from small catchments based on stochastic representation of storm events

K22.2.09 The basin storage and water balance analysis package (BSTOR)

K22.2.10 Hydrological rainfall runoff model (HYRROM)

K22.3.01 Urban rainfall-runoff model (SWMM)

K22.3.02 Computer program for project formulation - Hydrology (TR-20)

K22.3.03 General purpose rainfall/runoff model NAM

K22.3.04 Hydrological land surface and river basin model system - EGMO

K22.3.05 CAMOS for operating hydrological land surface and river models

K22.3.06 Combined simulation model for surface water and groundwater

K22.3.07 Runoff simulation model for basins containing reservoirs

K22.3.08 Programme package for hydrological model identification (PP)

\section{K35 STREAMFLOW SIMULATION AND ROUTING}

K35.1.01 Cross-section properties program (CSP)

K35.1.02 Channel routing Muskingum-Cunge method

K35.1.03 Operational calculation of the water storage in rivers from water level data

K35.1.04 Computation of water-surface profiles in open channels

K35.1.05 Numerical solution of the non-linear Muskingum method

K35.2.01 Monthly streamflow simulation (HEC-4)

K35.2.02 Multivariate streamflow generator for short and tong term cyclicity

$K$ 35.2.03 Lag and $K$ routing (NWSRFS-LAG/K)

K35.2.04 Dynamic wave operational model (DWOPER)

K35.2.05 One-dimensional hydro-dynamic modelling

K35.2.06 Water-surface profile computation model (WSPRO)

K35.2.07 Culvert hydraulic model

K35.2.08 Hydraulics graphics package (HGP)

K35.2.09 Interior drainage flood routing (INTORA) (723-J2-L279)

K35.2.10 Hydraulic computations in channels (HIDRAC)

K35.3.01 Dynamic rating curve model (DYNMOD)

K35.3.02 Channel routing - implicit solution of full equations

K35.3.04 Stream hydraulics package (SHP)

K35.3.05 Channel network computations

K35.3.06 Water surface profiles (HEC-2)

K35.3.07 WSP2 computer program (water surface profiles)

K35.3.09 MIKE11-A one dimensional modelling system for rivers and esturies

K35.3.10 Input detection as the inverse task of forecasting

K35.3.11 Nonlinear model "RIMO/RIDO" for streamflow routing

K35.3.12 River flow computation (RIFLOW)

K35.3.13 Branch-network dynamic flow model (BRANCH)

K35.3.14 Flow model for a one dimensional system of open channels based on the diffusion analogy (DAFLOW)

For additional components modeling estuary flows with temperature and salinity distribution see also subsections K54 Water temperature studies, and K55 Water quality studies. 
K45.1.01 Lake-routing using a monthly time interval

K45.1.03 Propagation of floods through reservoirs (PROPAGA)

K45.3.01 Reservoir operation model (KS2)

\section{K54 WATER TEMPERATURE STUDIES}

K54.2.03 Reservoir temperature stratification

K54.3.01 Model of thermal pollution propagation in a river (TEMPER)

K54.3.02 A computer code for forecasting heat and pollutant spreading in rivers (POLFOR)

K55 WATER QUALITY STUDIES

K55.1.01 Estimating contaminant loads in rivers

K55.2.01 Graphical and interactive software for detecting trends

K55.2.03 Longitudinal dispersion of stable pollutants in rivers (DISPER)

K55.2.04 Transport model for a one dimensional system of open channels (BLTM)

K55.3.01 Storage, treatment, overtlow, runoff model (STORM)

K55.3.02 Water quality for river-reservoir systems (WORRS)

K55.3.03 Salt wedge intrusion

K55.3.04 Mathematical model for two dimensional salinity distribution in estuaries

K55.3.05 Environmental (water quality) information software (RAISON/GEMS)

\section{K65 SEDIMENT STUDIES}

K65.2.01 Computation of reservoir sedimentation

K65.2.02 Scour and deposition in rivers and reservoirs

\section{K70 ECONOMIC EVALUATION OF WATER-RESOURCE PROJECTS AND FLOODING}

K70.1.02 Design, construction, commissioning and operation of small hydroelectric power (HEP) plants

K70.2.01 Hydropower analysis using streamflow duration procedures (HYDUR)

K70.3.01 Multipurpose river basin simulation model (MITSIM)

K70.3.04 Risk assessment of optimal firm water and energy production from hydroelectric projects (OPTWER)

K70.3.06 Interactive river system simulation program (IRIS)

\section{K75 DESIGN AND OPERATING POLICIES OF RESERVOIRS}

K75.1.01 Storage capacity of a reservoir for low-flow regulation

K75.1.02 Storage capacity of a flood-control reservoir

K75.2.01 Design of storage reservoirs by stochastic simulation

K75.2.02 Reservoir design (hydrology)

K75.2.04 Analysis of reservoir operation in the case of random drafts

K75.2.05 Operational control rules based on components

K75.3.01 Reservoir system analysis for conservation (HEC-3)

K75.3.02 Simulation of flood control and conservation systems (HEC-5)

\section{SECTIONL GROUNDWATER.}

\section{L10 ANALYSIS OF DATA FROM WELLS AND BOREHOLES}

L10.1.01 Computation of sea water-fresh water interface

L10.1.02 Determination of hydraulic conductivity by test pumping with observation wells

L10.1.03 Computation of drawdown of vertical and horizontal partially penetrating wells

L10.2.01 Pumping test analysis by analytical solutions (AQ-AT) 
L20.2.01 Ground water interface model

L20.2.03 Groundwater flow model (GRW2M)

L20.2.04 Modular finite-difference groundwater flow model (MODFLOW)

L20.3.01 Ground water salinity model

L20.3.02 Aquifer simulation system

L20.3.03 IDROSIM: a simulation model for flow in a coastal aquifer

L20.3.04 Multi-aquifer simulation system

L20.3.05 A model for unsaturated flow above a shallow water table (MUST)

L20.3.06 Determination of the position of a salt/fresh groundwater interface

L20.3.07 Pathlines and travel times based on analytical solutions (AO-AS)

L20.3.08 Groundwater potential analysis based on finite element solution (AQ-FEM)

L20.3.09 Groundwater pathlines and travel times analysis based on finite element solution (AQ-EF)

L20.3.10 Groundwater head drawdowns based on analytical solutions (AQ-AP)

The International Groundwater Modelling Centre, with offices in Delft, The Netherlands, and Golden, Colorado, USA, operates a clearing house for groundwater modelling software. For further details of the services that IGWMC offers, users should contact the HOMS Office.

\section{L30.3.01 Groundwater levels forecast}

\section{SECTION X MATHEMATICAL AND STATISTICAL COMPUTATIONS.}

X00.1.01 Statistics of monthly data

$X 00.1 .02$ Program to fit the gamma distribution

X00.1.03 Program to fit the log-normal distribution

X00.1.04 Gumbel fitting program

X00.1.05 Fitting the truncated Gumbel distribution with a known truncation point

X00.1.06 Program to fit the Gumbel distribution

X00.1.07 Fitting the truncated normal distribution with a known truncation point

$X 00.1 .09$ Program to fit the general extreme value distribution

X00.1.10 Program for frequency analysis

XO0.1.11 HYPROB: analysis of hydrological data

X00.2.01 Statistical programs for extreme value distributions

X00.2.02 Fitting of various distribution functions to a series of observations

X00.2.03 Frequency distributions for extreme value statistics

X00.2.05 Program for fitting six distributions to maximum discharge values

X00.2.06 Extreme value statistics (STATI)

XO0.2.07 Computational methods in hydrology (with FORTRAN programs)

X00.3.04 UNESCO IDAMS - Internationally developed data analysis and management software

\section{SECTION Y TRAINING AIDS IN OPERATIONAL HYDROLOGY.}

YO0.0.01 Manual for training of instructors of hydrological technicians

YOO.0.02 Manual of hydrometeorological instruments

YO0.0.03 Manual of the international course on operational hydrology

YO0.0.04 Video tape on field maintenance of hydrological instruments

Y00.0.05 Statistical analysis in hydrology

Y00.0.06 On tides and storm surges

YOO.0.07 Basic hydraulic principles of open-channel flow

Y00.0.08 Study guide for beginning course in groundwater hydrology 


\section{CLASSIFICATION SCHEME FOR HOMS COMPONENTS}

Section A Policy, planning, and organisation.

Section B Network design.

Section $C$ Instruments and equipment.

Coo General

C05 Water quality, instruments monitoring several variables

C06 Water temperature

CO9 Sediment Load

C10 Suspended load

C12 Bed load

C14 Wash load

C16 Chemical quality

C21 Biological quality

C25 General meteorological data; climate and weather stations

C26 Precipitation, general

C27 Precipitation, manual \& storage gauges

C30 Precipitation, recording and telemetering gauges

C33 Precipitation, measurement by radar

C35 Air temperature

C37 Soil temperature

C39 Humidity

C41 Sunshine hours

C43 Solar radiation

C45 Evaporation, general

C46 Evaporation, pans and tanks

C48 Evaporation, lysimeters

C52 Wind velocity and direction

C53 Snow, depth and water equivalent

C55 Soil moisture, general

C56 Soil moisture, soil samplers

C58 Soil moisture, nuclear methods

C60 Soil moisture, electrical methods

C62 Soil moisture, tensiometers

C65 Groundwater, level

C67 Groundwater, borehole loggers

C71 Water level or stage

C73 Stream discharge, flumes, weirs, ultrasonic, and electro-magnetic methods

C79 Water velocity, current meters or floats

C85 River gauging, general

C86 River gauging, cableways

C88 River gauging, cranes, bridge frames, winches, and reels

C90 River gauging, equipment for use in boats

C92 Ice measurements

Section D Remote sensing.

Section E Methods of observations.

EOO General

EO5 Water quality 
Sediment

Meteorological observations for hydrology

Snow and ice, glaciology

E55 Soil moisture

E65 Groundwater

E70 Surface water, level and flow

E71 Water level

E73 Discharge measurement, dilution gauging

E79 Velocity measurements, use of current meters

E85 Measurement of hydrological characteristics from maps

E88 Surveying

Section F Data transmission.

Section G Data storage, retrieval and dissemination.

GOO General

G05 Standards, manuals and recommendations

G06 Systems for storing general hydrological data

G08 Surface water or river data storage systems

G10 Groundwater data storage systems: levels, water chemistry, well yields and flows

G12 Meteorological data storage systems

G14 Water quality data storage systems

G20 General hydrological data tabulation programs

G25 Hydrological yearbooks

G30 Information or data dissemination systems

G40 Transfer of data between authorities, standards, recommendations, manuals and methods of coding

G42 Transfer of data between authorities, programs implementing the standards in G40

\section{Section H Primary data processing.}

HOO Systems processing several types of data

Standards, recommendations, manuals, etc. for primary data processing in general

H05 General water quality data

HO6 Water temperature data

HO9 Sediment transport data

H16 Chemical quality data

H21 Biological quality data

H25 General meteorological data for use in hydrology

H26 Precipitation data, non-radar

H33 Radar precipitation data, including calibration by comparison with telemetering gauges

H35 Air temperature data

H39 Air humidity data

H41 Solar data, sunshine hours or radiation

H45 Evaporation data

H52 Wind data

H53 Snow and ice data, snow cover, depth, water equivalent

H55 Soil moisture data

H65 Groundwater data

H7O Surface water (level and flow) general

H71 Water level data, river stage, lake or reservoir levels

$\mathrm{H} 73$ Discharge data, all ranges

H76 Derivation of rating curves, converting stage to flow by means of rating curves

H79 Water velocity data, computing discharge from point velocity measurements

H83 Processing of historical flood information 
Section Secondary data processing.

100 General

105 General water quality data

106 Water temperature data (Includes ice phenomena in rivers)

109 Sediment transport data

125 General meteorological data for use in hydrology

126 Precipitation data

136 Airborne pollution

141 Solar data, sunshine hours or radiation

145 Evaporation, general

150 Evaporation, computation from meteorological measurements

153 Snow data

155 Soil moisture data

160 Water balance

165 Groundwater levels

171 Water level data

173 Discharge data

180 Low flows

181 Floods and flood frequency analysis

Section J Hydrological forecasting models.

Models and procedures whose main purpose is the operational forecasting of various hydrological elements

J04 Forecasting streamflow from hydrometeorological data

Forecasting basin or catchment runoff, including urban runoff, using rainfall-runoff and/or snowmelt-runoff models.

J10 Streamflow routing for forecasting

River stage and flow forecasting using models based on hydrometric data (stage and flow) only, starting from simple empirical and regression relations or storage-discharge relations and extending to full dynamic streamflow routing models.

J15 Combined streamflow forecasting and routing models

Forecasting stage or flow in river systems using complex models which include both rainfall-runoff and/or snowmelt-runoff components as well as channel routing components.

J22 Seasonal flow forecasting

Seasonal flow forecasting, including volume of runoff, using deterministic or stochastic methods.

J28 Forecasting low flows

J32 Forecasting soil moisture

Forecasting soil moisture conditions including water demands for irrigation

$\mathrm{J45}$ Ice forecasts

Forecasting ice conditions in rivers, lakes and reservoirs 
J54 Forecasting surface water temperature

J55 Forecasting surface water quality

J65 Forecasting sediment yield

J80 Analysis of model performance

Methods of analyzing the performance of forecasting models

Section $\mathrm{K}$ Hydrological analysis for the planning and design of engineering structures and water-resource systems.

Models and procedures whose main purpose is hydrological analysis for planning, development, design, and management of water-resource systems, including studies of climatic change and man's influence.

K10 Regional analysis

Water resources inventories; regional flood flow, mean flow and low flow studies; analysis in general.

K15 Site-specific flood studies

Design floods, extent of flooding, flood plain mapping.

K22 Rainfall-runoff simulation models

Rainfall/snowmelt-runoff simulation models for the planning, development, design and management of water-resource systems. Coupled surface water/groundwater models. Models of the complete hydrological cycle.

K35 Streamflow simulation and routing

Models using only stage and flow data describing streamflow processes in rivers

K45 Routing through reservoirs and lakes

Models for routing flows through ponding areas, lakes, and reservoirs.

K54 Water temperature studies

Methods for water temperature studies, simulation and analysis in estuaries, streams, lakes and reservoirs

K55 Water quality studies

Methods for water quality studies, simulation and analysis in estuaries, streams, lakes and reservoirs

K65 Sediment studies

Methods for the simulation and analysis of sediment transport, reservoir sedimentation, scour, erosion and deposition 
K70 Economic evaluation of water-resource projects and flooding

Methods for the economic evaluation of water-resource development strategies. Flood damage estimation

K75 Design and operating policies of reservoirs

Reservoirs: design, determining volume required, operating rules, coupled real time forecasting and operational systems

Section L Groundwater

Models and procedures for the simulation, analysis, assessment and forecasting of groundwater

L10 Analysis of data from wells and boreholes

Pump tests, well logging, and mapping techniques

L20 Aquifer simulation models

Models for simulation, analysis and assessment of groundwater flow, temperature, and quality

L22 Calibration and verification of groundwater models

L30 Groundwater forecasting

Section $X$ Mathematical and statistical computations.

Section $Y$ Training aids in operational hydrology. 
